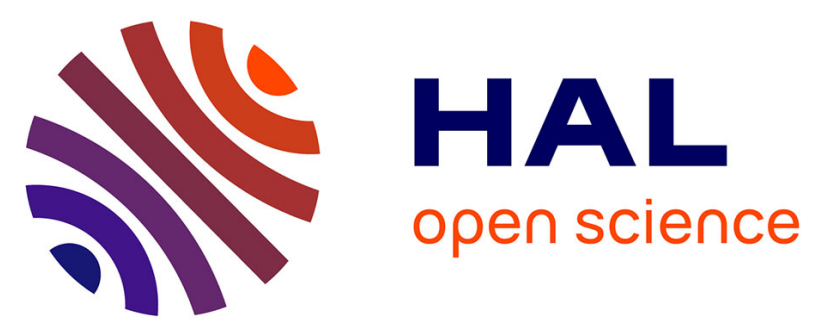

\title{
Unbalanced sediment budgets in the catchment-alluvial fan system of the Kuitun River (northern Tian Shan, China): Implications for mass-balance estimates, denudation and sedimentation rates in orogenic systems
} Marc Jolivet, Laurie Barrier, Stephane Dominguez, Laure Guerit, Gloria Heilbronn, Bihong Fu

\section{To cite this version:}

Marc Jolivet, Laurie Barrier, Stephane Dominguez, Laure Guerit, Gloria Heilbronn, et al.. Unbalanced sediment budgets in the catchment-alluvial fan system of the Kuitun River (northern Tian Shan, China): Implications for mass-balance estimates, denudation and sedimentation rates in orogenic systems. Geomorphology, 2014, 214, pp.168-182. 10.1016/j.geomorph.2014.01.024 . insu-00985283

\section{HAL Id: insu-00985283 \\ https://hal-insu.archives-ouvertes.fr/insu-00985283}

Submitted on 29 Apr 2014

HAL is a multi-disciplinary open access archive for the deposit and dissemination of scientific research documents, whether they are published or not. The documents may come from teaching and research institutions in France or abroad, or from public or private research centers.
L'archive ouverte pluridisciplinaire HAL, est destinée au dépôt et à la diffusion de documents scientifiques de niveau recherche, publiés ou non, émanant des établissements d'enseignement et de recherche français ou étrangers, des laboratoires publics ou privés. 


\title{
Unbalanced sediment budgets in the catchment-alluvial fan system of the Kuitun River (northern Tian Shan, China): implications for mass-balance estimates, denudation and sedimentation rates in orogenic systems
}

Marc Jolivet $^{\mathrm{a}, *}$, Laurie Barrier ${ }^{\mathrm{b}}$, Stéphane Dominguez ${ }^{\mathrm{c}}$, Laure Guerit ${ }^{\mathrm{b}}$, Gloria Heilbronn ${ }^{\mathrm{a}}$ and Bihong $\mathrm{Fu}^{\mathrm{d}}$

\footnotetext{
a Université Rennes 1, Laboratoire Géosciences Rennes, UMR 6118 CNRS/INSU, Campus de Beaulieu, 35042 Rennes, France

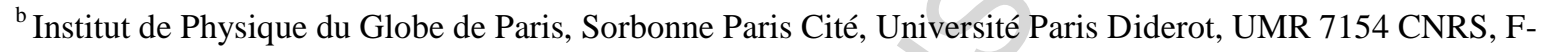
75005 Paris, France

${ }^{\text {c }}$ Université Montpellier 2, Laboratoire Géosciences Montpellier, UMR 5243 CNRS/INSU, 5 Pl. E. Bataillon, 34095 Montpellier, France

${ }^{\mathrm{d}}$ State Key Laboratory of Lithospheric Evolution, Institute of Geology and Geophysics, Chinese Academy of Sciences, Beijing, China
}

Corresponding author. Tel.: +33 (0)2 232367 46; Fax: +33 (0)2 232367 80; E-mail: Marc.jolivet@univrennes1.fr

\begin{abstract}
Mass balances are often used to calculate sediment fluxes in foreland basins and denudation rates in adjacent mountain ranges on intermediate to long timescales (from a few tens of thousand to million years). Here, we study the simple Quaternary catchment-alluvial fan system of the Kuitun River, in northern Tian Shan, to discuss some ideas about sediment storage, release, and bypass in relatively short (a $100 \mathrm{~km}$ long) sediment routing systems. This study shows that the Kuitun catchment and piedmont areas clearly present evidence of a significant and temporary storage of sediments during the Pleistocene. These sediments were then excavated and delivered farther into the foreland basin during the Holocene. The difference between the volumes of materials released from the catchment and piedmont areas $\left(5.5 \pm 1.7 \mathrm{~km}^{3}\right)$ and the volume stored in a contemporaneous fan downstream $\left(2.6 \pm 0.6 \mathrm{~km}^{3}\right)$ indicates that the latter did not trap the whole sediment load transported by the river. The alluvial fan was bypassed by 27 to $78 \%$ of this load toward its distal alluvial plain. If this value is well estimated, it implies a major volumetric partitioning of the deposits between the fan and the alluvial plain, with a very high sedimentation rate in the fan $\left(1.97 \pm 0.52 \mathrm{~mm} \cdot \mathrm{y}^{-1}\right)$
\end{abstract}


and a much lower one downstream $\left(0.11 \pm 0.11 \mathrm{~mm} \cdot \mathrm{y}^{-1}\right)$. However, this volumetric partitioning might only occur during periods with a very specific hydrological regime such as the Holocene deglaciation. Eventually, the peculiar sediment storage and release pattern within the Kuitun catchment and piedmont areas during the Pleistocene and Holocene complicates the calculation of mean palaeodenudation rates using either sediment budgets or in situ produced cosmogenic nuclides.

Keywords: sediment budget; mass balance; sediment storage; alluvial fan; Holocene; Tian Shan

\section{Introduction}

Erosion in mountain ranges is a key parameter that partly controls the evolution of orogenic systems and their interactions with climate (e.g., Molnar and England, 1990; Raymo and Ruddiman, 1992; Ramstein et al., 1997; Willett, 1999; Whipple and Meade, 2006). However, denudation rates within mountain ranges are often difficult to estimate from the study of bedrock areas where the morphological markers of erosion are scarce and discontinuous. The alluvial terraces and sedimentary series that develop within neighbouring basins usually constitute a more perennial record of the denudation. Several studies have successfully exploited this capacity of sedimentary basins to retain the eroded material to derive erosion fluxes from regional mass balance calculations (e.g., Métivier and Gaudemer, 1997; Métivier et al., 1999; Kuhlemann, 2002; Barnes and Heins, 2008; Hinderer, 2012, and references therein). Knowing the surface of a catchment, as well as the volumes and ages of the eroded sediments deposited at its outlet, deriving a mean denudation rate is possible. Variations in space and through time of this mean denudation rate can then be translated into variations in tectonic uplift or climatic forcing (e.g., Métivier and Gaudemer, 1997; Métivier et al., 1999; Kuhlemann, 2002; Barnes and Heins, 2008).

However, this calculation methodology relies on two strong hypotheses: (i) the sediments deposited in the basin correspond to the bedrock material eroded contemporaneously in the catchment area (i.e., no intermediate storage from source to sink), and (ii) this material is entirely trapped in the studied sedimentary series. Consequently, this mass balance approach is usually applied to large relief basin systems where sediment storage in catchment areas can be considered as minimal and sediment outputs from basins as null or negligible (e.g., Métivier and Gaudemer, 1997; Métivier et al., 1999; Kuhlemann, 2002; 
Barnes and Heins, 2008; Hinderer, 2012, and references therein). Indeed, when considering the denudation at the scale of a whole orogen (more than a few 10,000 $\mathrm{km}^{2}$ ) and over long timescales (a few $100 \mathrm{ky}$ to several Ma), the proportion of sediments delivered to the neighbouring basins is usually very large compared to the total amount of stored sediments. Consequently, the sediment fluxes in these basins can be reliably converted into denudation rates and directly related to the topographic evolution of the catchment areas (e.g., Métivier and Gaudemer, 1997; Kuhlemann, 2007; Barnes and Heins, 2008).

This approach is sometimes also applied to catchment-fan systems (e.g., Kiefer et al., 1997; Oguchi, 1997; Allen and Hovius, 1998; Jayko, 2005; Hinderer, 2012, and references therein). Those are the smallest and simplest complete sediment routing systems that can be found in continental contexts (Densmore et al., 2007; Allen, 2008). They are composed of an upland catchment area, where sediments are produced, associated with an adjacent alluvial fan where some or all of those sediments are deposited. However, at the scale of those systems (extending typically from a few $10 \mathrm{~km}^{2}$ to several $1000 \mathrm{~km}^{2}$ and developing over a few $10 \mathrm{ky}$ to a few $100 \mathrm{ky}$ ), the reliability of the negligible catchment storage and fan bypass hypotheses is still a key question in mass balance studies.

Before being delivered downstream, the material eroded within a catchment area can be partially stored for long periods compared to the development timescales of fans (Fig. 1) (e.g., Church and Ryder, 1972; Church and Slaymaker, 1989; Brooks, 1994; Hinderer, 2012, and references therein). This hillslope and valley storage, along with its release, can lead to apparent variations in sediment yield disconnected from the prevailing tectonic or climatic boundary conditions (e.g., Church and Ryder, 1972; Church and Slaymaker, 1989; Brooks, 1994; Coulthard et al., 2005) or to buffering the system response against their changes (e.g., Coulthard et al., 2002; Phillips, 2003). Thus, over intermediate timescales (a few 10 ky to a few $100 \mathrm{ky}$ ) that include large climatic changes during the Quaternary, varying or constant accumulation rates at the outlet of a catchment can be completely disconnected from the contemporaneous mean denudation rate. For example, during interglacial periods, a sudden release of sediments stored in a catchment area during glacial periods could artificially increase the sediment accumulation rate in a fan compared to the effective basement denudation upstream, which will then be overestimated. Conversely, trapping sediments in a catchment area could artificially decrease the sediment accumulation rate in the corresponding fan leading to underestimation of the catchment denudation rate. However, as far as we know, the proportion of sediments stored in catchment areas compared to the total 
amount of transported load is rarely assessed for periods longer than several millennia (Jordan and Slaymaker, 1991; Hinderer, 2012 and references therein).

Additionally, estimates of the sediment bypass through alluvial fans remain scarce (Kiefer et al., 1997; Oguchi, 1997; Allen and Densmore, 2000). In previous studies, catchment-fan systems were often considered as essentially closed in terms of sediment budget (e.g., Whipple and Trayler, 1996; Allen and Hovius, 1998; Jayko, 2005; Densmore et al., 2007; Giles, 2010), and for those that were not, quantifications are usually lacking (e.g., Denny, 1965; Allen and Hovius, 1998; Carretier and Lucazeau, 2005). Though variations in the amount of sediment bypass through time could also lead to apparent variations in accumulation rate disconnected from boundary condition changes or could buffer the system response against these changes. An important sediment bypass will artificially decrease the sediment accumulation in a fan compared to the effective sediment exportation from its catchment area. As a result, the apparent denudation rate calculated from this accumulation rate will be underestimated. In theory, sediment bypass can be assessed by comparing the amount of sediments accumulated in a fan and deposited in its downstream alluvial plain or exported from its upstream catchment area during a given period of time. Practically, this comparison requires a volumetric mapping of the sediments deposited in the fan and lying in the plain or coming from the source area. Unfortunately, the data (outcrops or wells) and markers (terraces), which are necessary to know the extension of these deposits in depth and the location of their source area, are often too scattered or even nonexistent in natural systems.

The catchment-fan system of the Kuitun River located on the northern side of the Tian Shan Range offers a natural case study for sediment storage, release, and bypass (Fig. 2). In that region, the rivers built several outstanding Quaternary alluvial fans and terraces, which have recorded the regional tectonic and climate evolution (e.g., Avouac et al., 1993; Molnar et al., 1994; Poisson, 2002; Zhou et al., 2002; Fu et al., 2003; Poisson and Avouac, 2004; Lu et al., 2010a,b). So far, alluvial deposits and surfaces associated with these features were essentially studied in the piedmont of the range, and the catchment areas inside the chain have not yet been investigated. However, using one of the only two roads that cross the mountain range, the Kuitun River can be followed up to its source. Along that road, evidence shows that the present river valley was previously filled by a large amount of unconsolidated sediments that have been subsequently washed away downstream where they have built a fan during the Holocene. This paper presents results of a mass balance performed on the sediments eroded and deposited throughout this history, based on morphosedimentary maps and measurements 
elaborated from field observations, satellite images, and SRTM3 digital elevation models. This mass balance documents the respective amounts of sediment load eroded from the catchment area and its piedmont and deposited in their foreland during the Holocene. It shows that, on intermediate timescales (a few $10 \mathrm{ky}$ to a few $100 \mathrm{ky}$ ), sediment storage within ranges and sediment bypass through their foreland alluvial fans can be major features of sediment budgets in catchment-fan systems. Based on the calculated sediment volumes, a discussion about the meaning of the derived denudation and sedimentation rates is provided.

\section{The Kuitun catchment-fan system}

\subsection{Geological setting}

The Kuitun River flows through the northern side of the Tian Shan Range in China. This 2500-km-long and up to 7400-m-high mountain belt extends through western China, Kazakhstan, and Kyrgyzstan (Fig. 2). After a complex Palaeozoic and Mesozoic orogenic history (e.g., Windley et al., 1990; Allen et al., 1992; Gao et al., 1998; Zhou et al., 2001; Laurent-Charvet et al., 2002), the Tian Shan was reactivated during the Cenozoic by the India-Asia collision (e.g., Tapponnier and Molnar, 1977; Avouac et al., 1993; Hendrix et al., 1994; Dumitru et al., 2001; Charreau et al., 2006; Jolivet et al., 2010, and references therein).

To the north, the range is separated from its foreland, the Junggar basin, by three series of east-west oriented fault propagation folds and thrust faults. A major thrust zone generally separates this faulted and folded piedmont from the exhumed basement that forms the high range (e.g., Avouac et al., 1993; Burchfield et al., 1999; Charreau et al., 2008; Chen, 2010; Chen et al., 2011).

In this piedmont, the rivers flowing northward from the range have alternatively formed well-developed alluvial fans and incised valleys flanked by terraces (e.g., Avouac et al., 1993; Lu et al., 2010a,b). Based on geomorphologic, stratigraphic, and chronologic studies, the development of the Kuitun alluvial fans and terraces (Figs. 3 and 4) has been recently investigated in terms of tectonic and climate forcing (Avouac et al., 1993; Molnar et al., 1994; Poisson, 2002; Poisson and Avouac, 2004; Charreau et al., 2009, 2011).

At the scale of a few million years, Charreau et al. (2009) proposed that thrusting of the range over its foreland is the main factor governing the progradation and aggradation of the Kuitun fan system. At the same timescale, Charreau et al. (2011) also suggested a strong impact of climate changes on sediment fluxes in the Kuitun area. Indeed, denudation rates 
derived from the in situ produced cosmogenic ${ }^{10} \mathrm{Be}$ concentrations of the sediments deposited in the Kuitun piedmont largely increased between 2.5 and $1.7 \mathrm{Ma}$, contemporaneously with the onset of the Quaternary ice ages. Since 1.7 Ma, they recovered the values generally observed prior to $2.5 \mathrm{Ma}$.

Finally, at the end of the Quaternary, the Kuitun River experienced a fan aggradation incision cycle. During the last glacial period, the river built a large fan at the outlet of the range (Fig. 3). Then, at the glacial-interglacial transition about $11 \mathrm{ka}$ ago, the stream incised this old fan and formed an up to 300-m-deep canyon flanked by stepped terraces (Molnar et al., 1994; Poisson, 2002; Poisson and Avouac, 2004). Contemporaneously to this entrenchment, a new fan initiated farther downstream within the Junggar basin (Avouac et al., 1993; Poisson, 2002) (Fig. 3).

This recent fan aggradation-incision cycle is clearly climate-driven as all the rivers on the northern side of the Chinese Tian Shan share the same history around the same times, during the last glacial and interglacial periods (Molnar et al., 1994; Poisson, 2002; Poisson and Avouac, 2004; Lu et al., 2010a,b). Moreover, the location of the river incisions does not correlate with the tectonic structures. For example, along the Kuitun canyon, tectonic uplift affects only a zone of about $5 \mathrm{~km}$ in length, corresponding to a growing anticline (the Dushanzi anticline) that locally accounts for only $10 \%$ of the total incision (Poisson, 2002; Poisson and Avouac, 2004). Consequently, the recent morphologic and sedimentary evolution of the Kuitun River system cannot be explained through local tectonic or autogenic processes.

\subsection{Morphological features of the Kuitun system}

The Kuitun River catchment extends within the Palaeozoic basement of the range and corresponds to one of the largest catchments in the northern piedmont (Graveleau, 2008). Its surface is about $1940 \mathrm{~km}^{2}$, and its mean altitude is close to $2100 \mathrm{~m}$ (Fig. 3). The source of the Kuitun River is situated within a wide glacial valley at an altitude of about $3700 \mathrm{~m}$. The drainage divide between the Kuitun catchment and those of the rivers flowing toward the Hexilagen basin to the south is marked by a series of ice caps and glaciers, some of them reaching altitudes of nearly $5000 \mathrm{~m}$. The Kuitun catchment is mainly fed by summer rains and snow or ice melt. Hence, the Kuitun River mostly flows from May to October, with a mean annual water discharge of $20 \mathrm{~m}^{3} / \mathrm{s}$ (Poisson and Avouac, 2004).

Inside the Kuitun catchment area, only one major tectonic structure (the $F_{2}$ fault on Figs. 3 and 4A) has been recognized, but it does not affect the topography of the riverbed, or 
at least within the resolution of the SRTM3 data (Fig. 4A). Additionally, no seismic activity or recent fault scarp is observed along that structure that can be considered as nonactive. Downstream, the outlet of the Kuitun catchment in the Junggar basin is localized by the major basement thrust fault $\left(\mathrm{F}_{1}\right)$ that controls the front of the high range (Figs. 3, 4A, 4B) (Avouac et al., 1993; Poisson, 2002). Immediately north of this outlet, the Kuitun River developed a major pre-Holocene alluvial fan $\left(f_{p}\right)$. About $620 \mathrm{~km}^{2}$, this fan is affected by the Dushanzi fault-bend anticline that marks the propagation of the deformation toward the basin (Fig. 3) (e.g., Poisson, 2002; Poisson and Avouac, 2004; Graveleau, 2008).

During the Holocene, the Kuitun River incised an up to 300-m-deep and 30-km-long linear canyon into the piedmont, cutting through its pre-Holocene fan (Figs. 3, 4, 4B). Looking at the extensive terrace system preserved on both sides of the canyon, Poisson and Avouac (2004) showed that incision occurred in two phases. During early to mid-Holocene (12.5 to $6 \mathrm{ka} \mathrm{BP}$ ), incision occurred in a large valley with moderate incision rates and a rapid decrease of the river slope. This phase was followed by a second stage of entrenchment of a narrower valley with a rapid incision rate and a slow decrease of the river slope. The authors explained this evolution by a dynamic adjustment of the hydrological system to climate changes: during the Early Holocene, wetter conditions induced an about three times higher water discharge, whereas during the middle to late Holocene a more arid climate prevailed.

Along the Kuitun canyon (Figs. 4A and B), at least five levels of terraces ( $T_{1}$ to $T_{5}$ ) have been recognized and dated from about 11 to $3.3 \mathrm{ka}$ BP (abandon age) using OSL (optically stimulated luminescence) and $\mathrm{C}^{14}$ dating (Molnar et al., 1994; Poisson and Avouac, 2004). The pre-Holocene fan in which the canyon was incised must thus have been abandoned around 12.5 to $11 \mathrm{ka}$. Accordingly, in order to simplify the following discussion, the pre-Holocene fan $f_{p}$ will be refered below as the Pleistocene fan, although its onset age is unknown.

The slope of the Pleistocene fan measured by Poisson and Avouac (2004) from a SPOT DEM is $2.05 \%$ and slightly higher than the slope of the various terraces in the canyon. The slopes measured in this study using SRTM3 data vary between 1.3 and $1.8 \%$ (increasing with the increasing relative age of the terraces), which is compatible with the 1.3 to $2.0 \%$ slopes measured by Poisson and Avouac (2004). Finally, the slope of the river bed varies along the profile from 1.2\% in the piedmont segment (Poisson and Avouac, 2004, reported a value of $1.1 \%$ for the same section), to $2.0 \%$ in the central segment between the outlet of the catchment area and the strong topographic change observed after about $50 \mathrm{~km}$ along the river profile (Fig. 4), and finally $1.4 \%$ in the upper part of the measured profile. 
Within the upper (southern) part of the Pleistocene fan surrounding the Kuitun canyon, remnants of older and strongly dissected surfaces are exposed, probably corresponding to older incised fans (Fig. 3). However, those surfaces, designated as old surfaces (Fig. 3), will not be discussed further in this work.

To the north of the Kuitun Pleistocene fan (i.e., downstream of the Kuitun canyon), the river built a Holocene fan $\left(f_{h}\right)$ that is much smaller than the previous one (Fig. 3). It comprises an early and a mid-late Holocene part with an average combined surface of 138 $\mathrm{km}^{2}$ and a very low mean slope of $0.94 \%$. However, the river most certainly carries finegrained sediments farther into the Junggar basin, building an alluvial plain extending as far as the Ebi Lake to the northwest (Fig. 2). In addition to the Holocene fan of the Kuitun River, the topography generated by the growing folds and faults in the piedmont, as well as by the uplift of the basement, also induced the formation of numerous small fans around and on the Pleistocene fan (Fig. 3). However, those secondary fans do not bring sediments directly into the Kuitun River. Finally, to the north of this fan system, undated large and mostly flat surfaces are preserved, some of them covered by the southern reach of the extensive aeolian dune field of the Junggar basin (Fig. 3).

\section{Evidence for past sediment storage and release}

Figure 5 presents a series of pictures taken along the Kuitun River from its source down to the outlet of its catchment area (see Fig. 3 for the picture location). In the source area, at a river altitude of about $3000 \mathrm{~m}$ or more, high angle colluvial fans are exposed all along the banks of glacial valleys filled with moraines that are currently entrenched by streams flowing on their surface (Fig. 5A). Immediately below, around $2500 \mathrm{~m}$ in altitude, large remnants of incised moraine are also preserved inside the Kuitun and tributary valleys (Fig. 5B). Within the latter, the surfaces of the moraines are located high above the Kuitun river bed, at the same level as the apex of all the colluvial fans on the valley slopes (Fig. 5B).

A little bit downstream, at a stream elevation close to $2215 \mathrm{~m}$, the first evidence of high, elevated terraces are exposed in a small lateral valley to the west, about $135 \mathrm{~m}$ above the Kuitun river bed (Fig. 5C). Near the same place, a flat surface that may correspond to an erosion surface is also visible on top of a crest at roughly the same altitude. Farther down, at a river altitude of about $2100 \mathrm{~m}$, Fig. 5D shows two strath terraces preserved along the western river bank and younger (i.e., lower compared to the riverbed altitude) than the ones on Fig. $5 \mathrm{C}$. 
Downstream, at a river altitude of $1400 \mathrm{~m}$, a large lateral valley to the west of the Kuitun River is nearly completely filled with layered sediments (Figs. 5E and 5F), which are attributed to upper Eocene on the Chinese geological map (XBGMR, 1993). Those sediments are deeply incised by the present river system with a terrace clearly visible on the southern side of the valley, some $200 \mathrm{~m}$ above the Kuitun stream bed (Fig. 5F). Figure 5G was taken at the exit of the next lateral valley, which contains sediments as the previous one. Moreover, a fill terrace system composed of conglomerates is preserved on the western side of the Kuitun valley, some $300 \mathrm{~m}$ above the river bed. Patches of conglomerates are also visible high above these well-preserved terraces, indicating that this lateral valley might have been nearly filled like the one situated immediately to the south. Figure $5 \mathrm{H}$ taken from another point of view shows that at least $200 \mathrm{~m}$ of conglomerates are preserved near the exit of the valley.

Some $1.3 \mathrm{~km}$ downstream, at a river altitude of $1260 \mathrm{~m}$, a well-developed terrace system also occurs, the highest terrace $\left(\mathrm{T}_{\mathrm{a}}\right)$ being again about $200 \mathrm{~m}$ above the present Kuitun river bed (Fig. 5I). Those terraces have been labeled $T_{a}$ to $T_{f}$ because they form a coherent system but, owing to a lack of dating, they cannot be compared directly with the terraces in the piedmont. Finally, Figure 5J shows one of the most extensive remnants of terrace preserved on the eastern bank of the Kuitun River, between 2.5 and $1.5 \mathrm{~km}$ before the outlet of the range. Those surfaces are perched about $200 \mathrm{~m}$ above the present stream bed.

The position of those terrace remnants that could be recognized on satellite images (Landsat 7 and SPOT 5 images, as well as images available through Google Earth ${ }^{\circledR}$ ) has been reported on Fig. 4A. Within the range, the terraces are separated into three groups. The first group is composed of many terraces located very close to the river bed and are difficult to correlate between each other. A second group, located around $10 \mathrm{~km}$ south of the outlet of the range (river bed distance), is positioned about 50 to $100 \mathrm{~m}$ above the river bed. However, there is no apparent correlation between these terraces that are not represented elsewhere in the catchment area. Finally, the third group is formed by two sets of terrace remnants: one located about $200 \mathrm{~m}$ above the river bed near the outlet of the range (e.g., Fig. 5J), and a second one about $140 \mathrm{~m}$ above the river bed some $30 \mathrm{~km}$ south of the outlet.

Linking the surfaces measured on the eastern bank of the Kuitun River and belonging to this last group (i.e., 6 points) gives a line with a slope of $1.75 \pm 0.25 \%$, which is compatible with the slope measured for the oldest terraces in the piedmont (Fig. 4A). Correlation between the fewer surfaces on the western bank ( 3 points) gives a slope of $1.4 \pm 0.2 \%$, still in the range of the slopes measured in the piedmont. The error associated with these slope calculations is 
related to the error on the SRTM3 data estimated at $\pm 4 \mathrm{~m}$ in horizontal and a maximum of \pm $30 \mathrm{~m}$ in vertical. The vertical error associated with the SRTM3 data in flat areas is estimated around $10 \mathrm{~m}$; however, this error largely increases in mountainous areas (Shortridge and Messina, 2011). Furthermore, apart from an up to 10-m-high offset that could be caused by the thrust fault that separates the piedmont from the catchment area (a maximum vertical offset of $1 \mathrm{~mm} \cdot \mathrm{y}^{-1}$ has been assumed for the fault $\mathrm{F}_{1}$ by Avouac et al. (1993), but no field evidence for active deformation during the Pleistocene-Holocene period has been reported), all those surfaces seem to extend the surface of the Pleistocene fan upstream in the Kuitun valley (Fig. 4A). Indeed, from their altitude above the present river bed and the slope obtained by correlating them along the river profile, the higher terrace remnants observed within the central part of the Kuitun catchment are aligned with the surface of the Pleistocene fan in the piedmont. This indicates that alluvial deposits have filled a part of the catchment area with a slope in line with the one of the alluvial fan. In other words, these terraces are the remnants of an alluvial valley with a stream-bed profile collinear to its downstream fan, as it is now largely accepted for many other catchment-fan systems (e.g., Densmore et al., 2007, and references therein; Allen, 2008).

The catchment of the Kuitun River thus clearly shows evidence of sediment storage during at least the deposition of the Pleistocene fan. Older sediment, still exposed in some connected lateral valleys, especially to the west of the Kuitun River, may even be as old as upper Eocene (XBGMR, 1993), indicating that the Pleistocene situation may have occurred several times during the Cenozoic development of the range. All those deposits are now incised and exposed as terrace remnants on both sides of the present Kuitun valley, in relation to the Holocene release of the sediments previously stored in the catchment area.

\section{Holocene mass balance in the Kuitun system}

In order to evaluate the Holocene release of sediments from the catchment area and the piedmont of the Kuitun River, as well as the contemporaneous sedimentation and bypass within its Holocene fan, we performed a series of volume calculations. In the Kuitun catchment-fan system, three volumes of sediment transported during the Holocene can be estimated using field observations and SRTM3 DEM data: (i) the volume of sediments released from the Pleistocene valleys in the range, (ii) the volume of sediments excavated 
from the canyon through the Pleistocene fan downstream, and (iii) the volume of sediments deposited in the Holocene fan.

towing to the sharp topography of the area and the occurrence of glaciers, the SRTM3 data used in this study are incomplete, especially for the high altitudes. This problem was partially solved by interpolating the SRTM3 data with the GTOPO30 data (Fig. 6A). Moreover, the poorlydefined zone is restricted to high picks that cover only very small areas of the whole catchment outside the main river system considered in this work. Once the SRTM3 data were completed, volumes were assessed using the GMT ${ }^{\circledR}$ software (Smith and Wessel, 1990; Wessel and Smith, 1991, 1995a,b, 1998). Except within the catchment area (see above), an error of $\pm 4 \mathrm{~m}$ in horizontal and $\pm 10 \mathrm{~m}$ in vertical associated to the SRTM3 data (Shortridge and Messina, 2011) are taken into account in all the following calculations. Using this tool, paleosurfaces - such as (i) the floor of the Pleistocene alluvial valleys within the catchment, (ii) the top of the Pleistocene fan in the piedmont, and (iii) the bottom of the Holocene fan in the basin - were reconstructed and volumes were calculated from the differences of elevation between these surfaces and the present-day topography.

\subsection{Volume of sediments released from the catchment area}

Evaluating the volume of sediments released from the catchment area during the Holocene is complex, and only rough estimates can be provided. This volume has been calculated by filling the Kuitun and tributary valleys up to the surface of the pre-Holocene sediments in the catchment (Fig. 6).

Near the outlet of the range, the sediment thickness is constrained to $210 \pm 10 \mathrm{~m}$ above the present river bed by the height of the well-preserved terraces on the eastern side of the valley (Figs. 4A and 5J). In order to model the surface of the Pleistocene sediment infill of the catchment area, a planar surface has thus been generated using the slope calculated above $(1.75 \pm 0.25 \%)$ and the direction of the vector linking these terrace remnants to the second best-resolved sets of terraces located farther upstream on the eastern bank side of the river valley within the range (Fig. 4A and 6B). This methodological approach is based on two assumptions: i) the surface of the deposits within this valley can be considered as a flat plane; and ii) a simple interpolation between the terraces has been preferred because the number of available measurement points over the whole area is far too low for a tensile surface approach and because the size of the various remnant terraces is too small for an accurate slope 
projection. The volume of sediments eroded from the drainage system was then calculated as the volume enclosed between this planar surface and the present-day topography below (Figs. $6 \mathrm{C}$ and $6 \mathrm{D})$.

Following that method, the volume obtained for the Holocene incision of the Kuitun and tributary valleys is $2.1 \pm 0.7 \mathrm{~km}^{3}$. The $33 \%$ error associated to that volume derives from the errors on the slope of the calculated plane $(1.75 \pm 0.25 \%)$ and on the present-day topography caused by the error on the SRTM3 data $( \pm 4 \mathrm{~m}$ in horizontal and $\pm 30 \mathrm{~m}$ in vertical).

\subsection{Volume of sediments released from the piedmont}

The volume of sediments released from the piedmont during the Holocene can be assessed by filling the Kuitun canyon up to the surface of the Pleistocene fan of the river (Fig. 7).

Poisson (2002) estimated the volume of this canyon at $3.5 \pm 1.75 \mathrm{~km}^{3}$ measured by filling the canyon up to the oldest terrace $T_{1}$ between the basement thrust to the south and the southern limb of the Dushanzi anticline to the north. In the present study, the volume of the canyon has been calculated on its entire length, from the basement thrust to a point farther north than the Dushanzi anticline; and the incision has been filled up to the level of the Pleistocene fan $f_{p}$ (Figs. 3 and 7). In order to reconstruct the surface of this fan above the canyon, a planar surface aas been generated between the two sides of the incision (Fig. 7B). This reconstruction is based on the assumption that the surface of the fan included within the canyon can be considered has a flat plane. Indeed, the canyon is very narrow compared to the total width of the Pleistocene fan. This implies that the lateral curvature of the fan can be neglected (over a width of about $2 \mathrm{~km}$, it would be of less than $10 \mathrm{~m}$, i.e., below the resolution of the SRTM3 data). A first volume of sediments eroded from the canyon was thus calculated between this planar fan surface corresponding to the projection of the Pleistocene fan surface topography above the canyon and the bottom of the incision (Fig. 7C).

However, the Holocene growth of the Dushanzi anticline has locally uplifted the fan surface, which is now bent above the fold (see for example Fig. 6 of Poisson and Avouac, 2004). Accordingly, an additional volume of excavated sediments, which corresponds to a volume enclosed between the fan surface reconstructed as a plane and its real surface that is locally uplifted, must also be considered. This volume eroded from the growing fold within 
the Kuitun Pleistocene fan and calculated based on the fold geometry defined by Poisson (2002) and Poisson and Avouac (2004) was thus added to the volume of sediments exported from the canyon as calculated above.

All together, the volume calculated for the Holocene incision in the Kuitun piedmont is $4.8 \mathrm{~km}^{3}$, with a maximum uncertainty of about $10 \%$ owing to the error corresponding to the resolution of the SRTM3 data (see above) and to the one on the limits of the canyon. This last error is minimal in terms of variations of the calculated volume as the uncertainty on the exact shape of the edges of the canyon will only apply to the uppermost terrace level, which is only a few tens of meters high. The induced error on the volume will thus be within or lower than the error caused by the uncertainty on the SRTM3 data.

The calculated volume is consistent with the $3.5 \pm 1.75 \mathrm{~km}^{3}$ obtained by Poisson (2002), which was neither considering the portion of the canyon across the Dushanzi anticline nor the incision above the terrace $T_{1}$. Unfortunately, Poisson (2002) does not provide explanation for the $50 \%$ error on her calculated volume, and we cannot discuss the extreme values.

\subsection{Volume of sediments stored in the fan}

Finally, the volume of sediments stored in the Holocene fan can be estimated by considering its upper and lower surfaces (Fig. 8). In map view, the Holocene fan was defined as the area presenting a northward slope steeper than the mean slope of the surrounding alluvial plain. It includes an early Holocene lobe to the southeast and a mid-late Holocene one to the northwest (Figs. 3 and 8A). The most proximal part of these lobes was emplaced on the distal part of the Pleistocene fan, whereas their distal part rests on the Junggar alluvial plain (Fig. 3). The geometrical relationships between the two fans do not suggest that the Pleistocene fan has been eroded prior to the deposition of the Holocene one. Consequently, we assumed that the paleotopography of the Pleistocene fan has been preserved below the Holocene deposits. The paleotopography corresponding to the distal part of the Pleistocene fan has thus been estimated using its topography immediately around the apex of the Holocene fan. Downstream, the paleotopography of the Pleistocene plain on which this fan developed was then assumed to be close to the one of the present surrounding alluvial plain. The basal surface of the Holocene fan was thus reconstructed using the mean slope of the Pleistocene fan (around $2.05 \pm 0.15 \%$ ) until its toe in the south and the regional slope of the alluvial plain (around $0.16 \pm 0.08 \%$ ) to the north (Fig. 8B). According to the simple 
topography (a uniform slope that is not affected by tectonic deformation or erosion) of the distal part of the Pleistocene fan and of the alluvial plain around the small area covered by the Holocene fan (Fig. 3), its basal surface as extrapolated here represents probably the best estimate that can be made given the available observations. Therefore, the volume of the Holocene fan was calculated as the volume enclosed between this basal surface and the present-day topography of its topsurface (Fig. 8C).

The volume of this fan is $3.2 \mathrm{~km}^{3}$ with an uncertainty evaluated around $10 \%$. This uncertainty derives from the errors on the two slopes used to extrapolate the basal surface of the fan, the error on the SRTM3 data, and the error on the horizontal extend of the Holocene fan. This last error is difficult to estimate. However, variations in the mapping of the edges of the Holocene fan will affect areas where the thickness of the deposits is smaller $(<10 \mathrm{~m})$ than the resolution of the SRTM3 data.

\subsection{Sediment budget}

In summary, the volumes of the Holocene incisions within the Kuitun catchment and piedmont are, respectively, $2.1 \pm 0.7$ and $4.8 \pm 0.48 \mathrm{~km}^{3}$. However, a great part of the incised material was composed of Pleistocene conglomerates for which a porosity of $20 \pm 10 \%$ seems to be a reasonable value (Clarke, 1979). This porosity must be taken into account to estimate the real volumes of eroded matter, even if these values might be overestimated since the river incision has reached the crystalline or sedimentary basement below the Pleistocene conglomerates. The nonporous volumes of matter released from the catchment and piedmont during the Holocene are thus $1.7 \pm 0.8$ and $3.8 \pm 0.9 \mathrm{~km}^{3}$, respectively.

On the other hand, the volume of the Kuitun Holocene fan is $3.2 \mathrm{~km}^{3}$, with an uncertainty evaluated around 10\%. The stored material was composed of Holocene conglomerates for which a porosity of $20 \pm 10 \%$ seems also to be reasonable (Clarke, 1979). This porosity must once again be taken into account to estimate the real volume of deposited matter. The nonporous volume of matter stored in the Holocene fan is thus $2.6 \pm 0.6 \mathrm{~km}^{3}$.

Consequently, a difference of $2.9 \pm 2.3 \mathrm{~km}^{3}$ is observed between the nonporous eroded and deposited volumes in the Kuitun catchment-fan system during the Holocene. This clearly indicates that the fan did not trap the whole amount of the transported sediment load. According to the lower and higher values for the eroded and deposited volumes, between 27 and $78 \%$ of this load bypassed the Holocene alluvial fan toward its downstream alluvial plain. 
In the following discussion, note that we will refer to the porous and nonporous volumes calculated above as volumes of sediments and volumes of material, respectively.

\section{Discussion}

\subsection{Implication on sediment bypass through the fan}

In previous studies, catchment - fan systems are often considered as essentially closed (e.g., Whipple and Trayler, 1996; Allen and Hovius, 1998; Jayko, 2005; Densmore et al., 2007; Giles, 2010). In these works, the finest grain size fractions of the bedload and the suspended load, as well as the dissolved load, are estimated volumetrically small enough to be neglected in a mass balance calculation. However, the sediment budget performed above for the Kuitun system clearly indicates that a significant proportion of the matter transported by the river is deposited farther than the alluvial fan. As indicated above, at least 27 to $78 \%$ of the transported matter has bypassed this fan toward its downstream alluvial plain during the Holocene. Moreover, the volume of material delivered from the catchment area is potentially underestimated in this sediment budget owing to physical bedrock erosion on the valley sides that cannot be assessed in the absence of markers. This means that the distal outputs calculated here for the Holocene Kuitun catchment-fan system are probably a minimum value. Finally, the mass balance calculated above only deals with the solid load transported in the river. It does not include the dissolved load produced by chemical alteration of the bedrock in the catchment and piedmont areas or of the sediment particles in the stream. Taking this dissolved fraction into account will again increase the total amount of transported matter.

This is in good agreement with annual mass balances performed in the Urumqi River, a nearby stream similar to the Kuitun River (Liu et al., 2011). According to the measurements carried out within the catchment area of this last stream, the bedload seems to represent around 15 to $20 \%$ of the total transported load, whereas the suspended and dissolved loads respectively correspond to about 30 and $50 \%$ of the matter. If these values are similar in the Kuitun River, the main part of these suspended and dissolved loads are actually not trapped in the Holocene fan that is clearly made up of bedload deposits, as indicated by their gravelly grain size.

\subsection{Implications on sedimentation rates in the foreland}


Considering the volume of the Kuitun Holocene fan $\left(3.2 \mathrm{~km}^{3} \pm 10 \%\right)$, its area (138 $\mathrm{km}^{2}$ with an uncertainty of $10 \%$ corresponding to an error of a few pixels on the exact position of the fan limits) and its age of formation (11.75 $\pm 0.75 \mathrm{ky}$ from Molnar et al., 1994; Poisson, 2002; Poisson and Avouac, 2004), it is possible to assess a Holocene mean sedimentation rate for this fan. Equally distributed over its whole area, the sediments deposited in the fan would represent a mean thickness of $23.2 \pm 4.6 \mathrm{~m}$, which can be converted to a mean sedimentation rate of $1.97 \pm 0.52 \mathrm{~mm} \cdot \mathrm{y}^{-1}$.

The same exercise can be done for the part of the Junggar basin that received the distal outputs of the Kuitun catchment-fan system. The Kuitun Holocene fan is the most proximal part of an about $3250 \mathrm{~km}^{2}$ endoreic (i.e., closed) sedimentary system with a base level corresponding to the Ebi Lake farther to the northwest (Fig. 2). The size of this sedimentary system has probably varied during the Holocene from the evolution of the other river systems surrounding the area. However, spread over these $3250 \pm 250 \mathrm{~km}^{2}$ (the uncertainty on this size estimate depends on the difficulty to assess the exact position of the limits of the Kuitun sedimentary system) with a porosity of $40 \pm 20 \%$ - which seems to be a reasonable value for sand, silt, or clay (McWhorter and Sunada, 1977) - the $2.9 \pm 2.3 \mathrm{~km}^{3}$ of material that bypassed the fan would correspond to a $1.25 \pm 1.26 \mathrm{~m}$ thick sediment layer. With an age of $11.75 \pm 0.75 \mathrm{ky}$ again for the onset of the sedimentation, this mean thickness can be converted to a mean sedimentation rate of about $0.11 \pm 0.11 \mathrm{~mm} . \mathrm{y}^{-1}$. The large error margins on the Holocene sediment thickness and sedimentation rate are linked to the addition of the uncertainties on the volume calculations (i.e., of the uncertainties on the volumes eroded from the catchment area, eroded in the canyon and stored in the Holocene fan), as well as to the large uncertainty on the surface of the sedimentation area within the alluvial plain. However, given that sediment bypass through the Holocene fan has been clearly demonstrated, some sedimentation has to occur in the alluvial plain. A value of $0 \mathrm{~mm} \cdot \mathrm{y}^{-1}$ within the alluvial plain is thus excluded, while the value of $0.22 \mathrm{~mm} \cdot \mathrm{yr}^{-1}$ should be considered as an extreme maximum.

Several long-term (Quaternary and Tertiary) sedimentation rates have been estimated in the Junggar basin using 3D regional mass balances based on sediment volumes in the whole basin (Métivier and Gaudemer, 1997) or 1D magnetostratigraphy analysis in specific locations (Sun et al., 2004; Charreau et al., 2005, 2009, 2011; Gallaud, 2008; Lu et al., 2010a,b; Li et al., 2011). Charreau et al. $(2005,2011)$ have documented the sedimentation rate 
in the piedmont of the Kuitun system from 10 to 2 Ma. They estimated a mean value of $0.21 \pm$ $0.01 \mathrm{~mm} . \mathrm{y}^{-1}$, close to the other rates measured in the northern piedmont of the Tian Shan (Sun et al., 2004; Charreau et al., 2009; Lu et al., 2010a,b; Li et al., 2011). Métivier and Gaudemer (1997) assessed the sedimentation rate between the Kuitun piedmont and the Ebi Lake over a period from 5.3 to $0 \mathrm{Ma}$. They calculated mean values comprised between 0.02 and $0.1 \mathrm{~mm} . \mathrm{y}^{-}$ ${ }^{1}$ (see Fig. 5a and 5b of Métivier and Gaudemer, 1997). Finally, Gallaud (2008) estimated the sedimentation rate in the Ebi Lake from 5 to $<1$ Ma. She calculated mean values of about 0.07 and $0.13 \mathrm{~mm} . \mathrm{y}^{-1}$ respectively before and after $1.2 \mathrm{Ma}$.

Therefore, on a long timescale, all the assessed sedimentation rates are of the same order of magnitude (a few ten to a few hundred mm. $\mathrm{y}^{-1}$ ), with only a factor of 2 or 3 between the proximal and distal deposits. In contrast, at the scale of the Holocene, the sedimentation rate in the proximal part of the Kuitun drainage system $\left(1.97 \pm 0.52 \mathrm{~mm} \cdot \mathrm{y}^{-1}\right.$ calculated for the alluvial fan) seems to be more than 10 times higher than the one in its distal part $(0.11 \pm 0.11$ mm. $\mathrm{y}^{-1}$ calculated for the alluvial plain), the latter being of the same order of magnitude than the long-term rates.

Two hypothetical situations must be considered to explain this observation. First, the excavated volumes measured in this study are representative of the physical and chemical erosion in the range (i.e., the volume of material released from the Holocene incisions is large compared to the one delivered from the hillslopes of the Kuitun catchment, which is not taken into account in our sediment budget). In that situation, the matter stored in the alluvial plain is correctly assessed from the difference between these excavated volumes and the volume of material trapped in the alluvial fan. As a consequence, the relative proportion of matter deposited in the Holocene fan and its distal plain is well estimated and implies a major volumetric partitioning of the deposits between the two environments, with a high sedimentation rate in the fan and a lower one downstream. If so, this appears to be one of the first clear quantifications of such a volumetric partitioning in an entirely continental setting. However, given that the long-term sedimentation rates are of the same order of magnitude in the proximal and distal parts of the Kuitun drainage system, this volumetric partitioning might not be the main rule for the sediment dispersal in the Junggar basin. It might only occur during periods with a very specific hydrological regime, such as the Holocene deglaciation in the area (see Poisson and Avouac, 2004). This is supported by numerical models in which such a proximal-distal volumetric partitioning of the deposits can be observed within alluvial systems in relation with rapid variations in sediment or water fluxes (Marr et al., 2000). 
A second possibility is that the excavated volumes measured in this study are far from being representative of the physical and chemical erosion in the range (i.e., the volume of material released from the Holocene incisions is similar or small compared to the volume delivered from the hillslopes of the Kuitun catchment). In that situation, the matter stored in the alluvial plain is incorrectly assessed from the difference between these excavated volumes and the volume of material trapped in the fan. As a consequence, the volumetric partitioning of the deposits between the alluvial fan and its distal plain can be highly overestimated. However, the Holocene volumetric partitioning was unlikely close to the mean value deduced from the long-term sedimentation rates. If so, the Holocene sedimentation rate would have been only 2 or 3 times lower in the plain than in the fan, but a mean sedimentation rate higher than $0.5 \mathrm{~mm} . \mathrm{y}^{-1}$ over the whole Kuitun alluvial system (about $3388 \mathrm{~km}^{2}$ ) requires a nearly double value for the mean denudation rate within its catchment area (about $1940 \mathrm{~km}^{2}$ ). As a comparison, this kind of values is typically found in the Himalaya (e.g., Galy and FranceLanord, 2001; Vance et al., 2003), which is located in a much wetter climatic setting than the Tian Shan. Indeed, the denudation rates documented for the last 2 My in the Tian Shan are

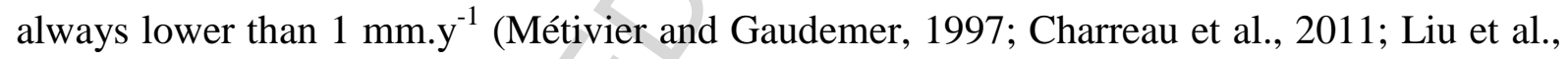
2011), with the highest values coming from cosmogenic isotopes that could be overestimated (see section 5.3 below).

Finally, regardless of the exact situation (with or without a negligible erosion on the hillslopes), the clear evidence of sediment storage and release within the Kuitun catchment and piedmont throughout the Pleistocene and Holocene means that, on an intermediate time scale (a few ky to $10 \mathrm{ky}$ ), the amount of sediments delivered to the basin could be disconnected from the contemporaneous erosion of the basement in the range. This sediment supply might rather correspond, at least during the early Holocene, to a recycling of the material eroded from the catchment bedrock during the previous, climatically different, Pleistocene period (e.g., Church and Ryder; 1972; Church and Slaymaker, 1989; Liu et al., 2011).

\subsection{Implications on denudation rates in the range}

Considering the volume of the Holocene excavations in the Kuitun catchment and piedmont, along with their area and age of formation, a Holocene mean incision rate of the river through its Pleistocene alluvial valley and alluvial fan can be assessed. Equally distributed over the whole canyon area $\left(62.1 \mathrm{~km}^{2}\right.$ with an uncertainty of $10 \%$ corresponding 
to an error of a few pixels on the exact position of the canyon limits), the volume of sediments excavated within the Pleistocene fan and the underlying deposits $\left(4.8 \mathrm{~km}^{3} \pm 10 \%\right)$ would represent a mean thickness of $77.3 \pm 15.4 \mathrm{~m}$. With an age of $11.75 \pm 0.75 \mathrm{ky}$ for the onset of the canyon development (Molnar et al., 1994; Poisson, 2002; Poisson and Avouac, 2004), this thickness can be converted to a mean incision rate of $6.6 \pm 1.7 \mathrm{~mm} \cdot \mathrm{y}^{-1}$, which is consistent with the previous studies in the area (Molnar et al., 1994; Poisson, 2002; Poisson and Avouac, 2004).

Similarly, distributed over the whole incisions area $\left(22.6 \mathrm{~km}^{2}\right.$ with an uncertainty of $10 \%$ corresponding to an error of a few pixels on the exact position of the incision limits), the volume of sediments excavated within the Pleistocene alluvial valleys $\left(2.1 \mathrm{~km}^{3} \pm 33 \%\right)$ would represent a mean thickness of $92.9 \pm 40 \mathrm{~m}$. Considering the same age of $11.75 \pm 0.75 \mathrm{kyr}$ for the onset of the excavation (Molnar et al., 1994; Poisson, 2002; Poisson and Avouac, 2004), this thickness can be converted to a mean incision rate of $7.9 \pm 3.9 \mathrm{~mm}_{\mathrm{yr}} \mathrm{r}^{-1}$. However, this incision rate is probably far from being representative of the denudation rate for the whole catchment area. Indeed, the measured incision has mainly developed through the poorly consolidated sediments stored in the Kuitun catchment during the Pleistocene, the erodibility of which being very likely higher than the one of the bedrock on the valley sides.

Therefore, assuming once again that the matter delivered from the hillslopes of the Kuitun catchment is negligible during the Holocene (i.e., the matter production in the catchment is dominated by the incision of the Pleistocene deposits), the material released from the alluvial valleys and artificially spread over the $1940 \mathrm{~km}^{2}$ of the watershed would represent a mean denudation rate $<0.1 \mathrm{~mm} \cdot \mathrm{y}^{-1}$. Although not representative of the true Holocene basement-rock erosion rate in the catchment, this mean value is of the same order of magnitude as short-term (present day) and long-term (Quaternary and Tertiary) denudation rates estimated for the Tian Shan range using the mass balances performed for the Urumqi River or the whole Junggar basin (Métivier and Gaudemer, 1997; Liu et al., 2011) (see section 5.1 above).

On the other hand, Charreau et al. (2011) documented mean denudation rates in the Kuitun system using in situ produced cosmogenic ${ }^{10} \mathrm{Be}$ concentrations for different periods between 9 and $0 \mathrm{Ma}$. Their values range from 0.1 to $1 \mathrm{~mm} \cdot \mathrm{y}^{-1}$ for most of their record, with some rates around $2 \mathrm{~mm} . \mathrm{y}^{-1}$ between 2.5 and $1.7 \mathrm{My}$. With the same approach, similar values are also found for other areas in the Tian Shan range (Puchol et al., 2012). The denudation 
rates estimated from cosmogenic ${ }^{10} \mathrm{Be}$ concentrations are thus higher than those assessed with mass balances and this discrepancy remains to be explained.

In situ produced cosmogenic nuclides and especially ${ }^{10} \mathrm{Be}$ are widely used to calculate the abandonment age of alluvial terraces (e.g., Lal, 1991; Ritz et al., 2006; Vassallo et al., 2007) or to determine mean denudation rates in catchment areas (e.g., Brown et al., 1995; Granger et al., 1996; von Blanckenburg, 2005; Blard et al., 2006; Charreau et al., 2011) from river sediments. In the case of buried deposits, the total concentration in ${ }^{10} \mathrm{Be}$ of a sediment $\left({ }^{10} \mathrm{Be}_{\mathrm{Tot}}\right)$ results from the ${ }^{10} \mathrm{Be}$ concentrations acquired or lost during (i) the exposure of the bedrock prior to erosion $\left({ }^{10} \mathrm{Be}_{\mathrm{Exp}}\right)$, (ii) the transport of the grains delivered by erosion $\left({ }^{10} \mathrm{Be}_{\text {Transp }}\right)$, (iii) their burial $\left({ }^{10} \mathrm{Be}_{\mathrm{Bur}}\right)$, and finally (iv) their modern exposure $\left({ }^{10} \mathrm{Be}_{\text {Reexp }}\right)$. A paleo-denudation rate can be calculated from ${ }^{10} \mathrm{Be}_{\mathrm{Tot}}$ if ${ }^{10} \mathrm{Be}_{\text {Transp }},{ }^{10} \mathrm{Be}_{\mathrm{Bur}}$, and ${ }^{10} \mathrm{Be}_{\text {Reexp }}$ can be assessed to infer the ${ }^{10} \mathrm{Be}_{\mathrm{Exp}}$ concentration, which depends on the nuclide paleoproduction rate and on the denudation rate when steady for a long time.

Normally, ${ }^{10} \mathrm{Be}_{\mathrm{Bur}}$ and ${ }^{10} \mathrm{Be}_{\text {Reexp }}$ can be estimated without too much difficulty by coupling the ages and rates of burial and modern exposure of the sedimentary archives with the rates of nuclide paleoproduction and radioactive decay (e.g., Blard et al., 2006; Charreau et al., 2011). Then, in a relatively short sediment routing system such as the Kuitun catchment-fan pair, sediment transport from the erosion to the deposition areas is generally seen as nearly instantaneous compared to the timescale of the other processes and ${ }^{10} \mathrm{Be}_{\text {Transp }}$ is neglected. However, in the case of a transient storage of sediments for intermediate (a few thousand to tens of thousand years) or long (a few hundreds of thousand to millions of years) time periods in the catchment area, the gains or losses of ${ }^{10} \mathrm{Be}$ during the transport can become important before the final deposition in the basin (e.g., Granger et al., 1996). In that situation, the concentration ${ }^{10} \mathrm{Be}_{\text {Transp }}$ can be significant enough to skew the denudation rate calculation.

The ${ }^{10} \mathrm{Be}$ in situ production in sediments from spallation reactions from rapid neutrons can be neglected for burial depths over $\sim 3 \mathrm{~m}$ (Lal, 1991). However, ${ }^{10} \mathrm{Be}$ in situ production from muon capture or reaction can occur at burial depth of several tens of meters of sediments (Braucher et al., 2003). Accordingly, when the deposits stored inside the catchment are thinner than a few tens of meters, the ${ }^{10} \mathrm{Be}$ average production in the sediment stack is greater than or equal to its radioactive decay. The resulting ${ }^{10} \mathrm{Be}_{\text {Transp }}$ is positive and adds to ${ }^{10} \mathrm{Be}_{\text {Exp }}$. Considering ${ }^{10} \mathrm{Be}_{\text {Transp }}$ as negligible (i.e., considering that ${ }^{10} \mathrm{Be}_{\text {Exp }}+{ }^{10} \mathrm{Be}_{\text {Transp }}$ is the concentration of ${ }^{10} \mathrm{Be}_{\mathrm{Exp}}$ only) would lead to underestimate the denudation rate. In contrast, when the sediments stored inside the catchment are thicker than a few tens of meters, the ${ }^{10} \mathrm{Be}$ 
decay can be greater than its average production in the sediment stack. If so, the resulting ${ }^{10} \mathrm{Be}_{\text {Transp }}$ is negative and subtracts to ${ }^{10} \mathrm{Be}_{\text {Exp }}$. Hence, considering ${ }^{10} \mathrm{Be}_{\text {Transp }}$ as negligible would lead to overestimating the denudation rate.

Consequently, when studying mean palaeodenudation rates in catchment areas, the evolution of the cosmogenic isotope concentration associated with sediment storage during several tens of thousands of years can be a problem. In the case of the Kuitun system, the up to 200-meters-thick Pleistocene deposits in the catchment implies that ${ }^{10} \mathrm{Be}_{\text {Trans }}$ is probably negative and that the Holocene ${ }^{10} \mathrm{Be}_{\operatorname{Exp}}$ values could be thus underestimated, leading to artificially high denudation rates. This might partially explain why the denudation rates estimated from cosmogenic ${ }^{10} \mathrm{Be}$ concentrations are higher than those assessed from mass balances.

Two other reasons might explain the difference in denudation rates. First, deriving denudation rates from cosmogenic ${ }^{10} \mathrm{Be}$ concentrations requires a steady state system (e.g., Brown et al., 1995; von Blanckenburg, 2005; Charreau et al., 2011). Given the strong tectonic activity and the climate changes that affected the northern Tian Shan Range during the late Tertiary-Quaternary period, such as steady state, might not be reached (Liu et al., 2011). Second, within the Kuitun catchment area, the quartz, producing rocks are very minor, mostly represented by Permian granites intruded within a Carboniferous volcanic arc (e.g., Charreau et al., 2012). All those granites are located within the upper reach of the catchment area where the cosmogenic production rate is the highest and the erosion mainly driven by glaciers. Although this has been taken into consideration by Charreau et al. (2011), a slight error in defining the exact proportion of sediment released from those high altitude areas might have a nonegligible effect on the final calculated denudation rates.

\section{Conclusion}

The sediment budget performed for the Holocene catchment - fan system of the Kuitun River allows for the testing of some ideas about sediment storage, release, and bypass in such systems on a natural case study.

The Kuitun catchment area clearly shows evidence of a significant storage of sediments during the Pleistocene. Over the same period, a large alluvial fan was built at the outlet of this catchment. These catchment and piedmont deposits were then largely excavated and delivered farther into the foreland basin during the Holocene. As a result, they are now 
incised and exposed as terrace remnants on both sides of the Kuitun valley, sometimes up to $200 \mathrm{~m}$ above the present-day riverbed, while a new fan forms downstream.

The difference between the volumes of material released from the catchment and piedmont areas during the Holocene $\left(5.5 \pm 1.7 \mathrm{~km}^{3}\right)$ and stored in the contemporaneous fan $\left(2.6 \pm 0.6 \mathrm{~km}^{3}\right)$ clearly indicates that the latter did not trap the whole amount of the sediment load transported by the river. At least 27 to $78 \%$ of this load has bypassed the alluvial fan toward the downstream alluvial plain. Moreover, the matter delivered from the catchment area is potentially underestimated in this sediment budget owing to physical and chemical bedrock erosion on the valley sides that cannot be estimated in the absence of markers. This means that the distal outputs calculated for the Holocene Kuitun catchment - fan system are probably a minimum value.

However, if the underestimation of these outputs is not too large (i.e., the Holocene catchment denudation is dominated by the incision of the Pleistocene deposits), the relative proportion of sediments stored in the alluvial fan and its downstream plain is well assessed and implies a major volumetric partitioning of the deposits between the two environments. In fact, during the Holocene, the sedimentation rate in the fan $\left(1.97 \pm 0.52 \mathrm{~mm}^{-1} \mathrm{y}^{-1}\right)$ could have been more than 10 times higher than the rate in the plain $\left(0.11 \pm 0.11 \mathrm{~mm} . \mathrm{y}^{-1}\right)$. Nevertheless, given that the long-term sedimentation rates are of the same order of magnitude in the proximal and distal part of the Kuitun depositional system, this volumetric partitioning might only occur during periods with a very specific hydrological regime such as the Holocene deglaciation in the region.

Finally, the transient storage and release of a large amount of sediments within the Kuitun catchment and piedmont areas during the Pleistocene and Holocene complicate the calculation of mean palaeodenudation rates. For example, the mean incision rates locally achieved through the poorly consolidated Pleistocene deposits (up to $7.9 \pm 3.9 \mathrm{~mm} . \mathrm{y}^{-1}$ ) are certainly far from being representative of the Holocene mean erosion rate of the catchment area, which is mainly composed of crystalline bedrock. Consequently, the amount of sediments delivered to the basin is probably also disconnected from the contemporaneous denudation of the basement in the range. This sediment supply might rather correspond, at least during the early Holocene, to a recycling of the material eroded from the catchment bedrock during the previous, climatically different, Pleistocene period. This sediment recycling could also represent a source of error for the calculation of mean palaeodenudation rates using in situ produced cosmogenic nuclides. Indeed, in the case of sediment storage in 
the catchment area over intermediate (a few thousand to tens of thousand years) or long (a few hundreds of thousand to millions of years) periods, the gains or losses of cosmogenic isotopes in between the erosion and deposition times can be significant enough to partially skew the denudation rate estimates.

Therefore, sediment storage, release, and bypass in catchment-fan systems can be major features of mass balances between mountain ranges and their forelands. Accordingly, they should be considered in future works on orogenic sediment fluxes and denudation rates.

\section{Acknowledgements}

This work was supported by the Agence Nationale pour la Recherche program - ANR Blanc 05-0143-01, the Chinese project kzcx3-sw-147, the Darius program, the French CNRS-INSU, and by the French-Chinese SALADYN International Associated Laboratory. We thank Y. Chen and Q. Wang for their help during fieldwork. This paper is the IPGP contribution \#3385.

\section{References}

Allen, M.B., Windley, B.F., Zhang, C., 1992. Paleozoic collisional tectonics and magmatism of the Chinese Tien Shan, central Asia. Tectonophysics 22, 89-115.

Allen, P. A., 2008. Time scales of tectonic landscapes and their sediment routing systems. In: Gallagher K., Jones S.J., and Wainwright J. (eds), Lanscape Evolution: Denudation, Climate and Tectonics Over Different Time and Space Scales (Ed. by K. Gallagher, S.J. Jones and J. Wainwright), Special Publication of the Geological Society of London 296, $7-28$.

Allen, P.A., Densmore, A.L., 2000. Sediment flux from an uplifting fault block. Basin Research 12, 367-380.

Allen, P.A., Hovius, N., 1998. Sediment supply from landslide-dominated catchments: implications for basin-margin fans. Basin Research 10, 19-35.

Avouac, J.P., Tapponnier, P., Bai, M., You, H., Wang, G., 1993. Active thrusting and folding along the northern Tien Shan and Late Cenozoic rotation of the Tarim relative to Dzungaria and Kazakhstan. Journal of Geophysical Research 98, 6755-6804.

Barnes, J.B., Heins, W.A., 2008. Plio-Quaternary sediment budget between thrust belt erosion and foreland deposition in the central Andes, southern Bolivia. Basin Research 21, 91- 
109.

Blard, P.H., Bourles, D., Lave, J., Pik, R., 2006. Applications of ancient cosmic-ray exposures: theory, techniques and limitations. Quaternary Geochronology 1, 59-73.

Braucher, R., Brown, E.T., Bourles, D.L., Colin, F., 2003. In situ produced ${ }^{10} \mathrm{Be}$ measurements at great depths: implications for production rates by fast muons. Earth and Planetary Science Letters 211, 251-258.

Brooks, G.R., 1994. The fluvial Reworking of Late Pleistocene Drift, Squamish River Drainage Basin, Southwestern British Colombia. Géographie physique et Quaternaire 48(1), 51-68. Brown, E.T., Stallard, R.F., Larsen, M.C., Raisbeck, G.M., Yiou, F., 1995. Denudation rates determined from the accumulation of in situ produced $10 \mathrm{Be}$ in the Luquillo experimental forest, Puerto-Rico. Earth Planetary Science Letters 129, 193-202.

Burchfield, B.C., Brown, E.T., Qidong, D., Xianyue, F., Jun, L., Molnar, P., Jianbang, S., Zhangming, W., Huichuan, Y., 1999. Crustal shortening on the margins of the Tien Shan, Xinjiang, China. International Geological Review 41, 665-700.

Carretier, S., Lucazeau, F., 2005. How does alluvial sedimentation at range fronts modify the erosional dynamics of mountain catchments? Basin Research 17, 361-381.

Charreau, J., Chen, Y., Gilder, S., Dominguez, S., Avouac, J.P., Sen, S., Sun, D.J., Li, Y.A., Wang, M.W., 2005. Magnetostratigraphy and rock magnetism of the Neogene Kuitun He section (northwest China): Implications for late Cenozoic uplift of the Tianshan mountains. Earth and Planetary Science Letters 230, 177-192.

Charreau, J., Gilder, S., Chen, Y., Dominguez, S., Avouac, J-Ph, Sen, S., Jolivet, M., Li Y. Wang, W.M., 2006. Late Cenozoic erosion history of the Tianshan Mountains as recorded in the Yaha section, Tarim Basin, China. Geology 34, 181-184.

Charreau, J., Avouac, J-Ph., Chen, Y., Dominguez, S., Guilder, S., 2008. Miocene to present kinematics of fault-bend folding across the Huerguosi anticline, northern Tianshan (China), derived from structural, seismic, and magnetostratigraphic data. Geology 36, 871-874.

Charreau, J., Gumiaux, C., Avouac, J-Ph., Augier, R., Chen, Y., Barrier, L., Gilder, S., Dominguez, S., Charles, N., Wang, Q., 2009. The Neogene Xiyu Formation, a diachronous prograding gravel wedge at front of the Tianshan: Climatic and tectonic implications. Earth Planetary Science Letters 287, 298-310.

Charreau, J., Blard, P-H., Puchol, N., Avouac, J-Ph., Lallier-Vergès, E., Bourlès, D., Braucher, R., Gallaud, A., Finkel, R., Jolivet, M., Chen, Y., Roy, P., 2011. Paleo-erosion rates in Central Asia since $9 \mathrm{Ma}$ : a transient increase at the onset of 
Quaternary glaciations? Earth Planetary Science Letters 304, 85-92.

Chen, K., 2010. Le piedmont nord du Tianshan: cas d'école d'un front de chaine immature. PhD Thesis, Université d'Orléans, 224 p. http://tel.archives-ouvertes.fr/tel-00574614/fr/

Chen, K., Gumiaux, C., Augier, R., Chen, Y., Wang, Q., Lin, W., Wang, S., 2011. The Mesozoic palaeorelief of the northern Tian Shan (China). Terra Nova 23, 195-205.

Church, M., Ryder, J.M., 1972. Paraglacial Sedimentation: A Consideration of Fluvial Processes Conditioned by Glaciation. Geological Society of America Bulletin 83, 3059-3072.

Church, M., Slaymaker, O., 1989. Disequilibrium of Holocene sediment yield in glaciated British Columbia. Nature 337, 452-454.

Clarke, R.H., 1979. Reservoir properties of conglomerates and conglomeratic sandstones. American Association of Petroleum Geologists Bulletin 63, 799-803.

Coulthard, T.J., Lewin, J., Macklin, M.G., 2005. Modelling differential catchment response to environmental change. Geomorphology 69, 222-241.

Denny, C.S., 1965. Alluvial Fans in the Death Valley Region California and Nevada. U.S. Geological Survey Professional Paper 466, Washington, U.S., 62 pp.

Densmore, A.L., Allen, P.A., Simpson, G., 2007. Development and response of a coupled catchment-fan system under changing tectonics and climatic forcing. Journal of Geophysical Research 112, F01002, doi :10.1029/2006JF000474.

Dumitru, T.A., Hendrix, M.S., 2001. Fission-track constraints on Jurassic folding and thrusting in southern Mongolia and their relationship to the Beishan thrust belt of northern China. Geological Society of America Memoir 194, 215-229.

Dumitru, T.A., Zhou, D., Chang, E.Z., Graham, S.A., 2001. Uplift, exhumation, and deformation in the Chinese Tian Shan. Geological Society of America Memoirs, 194, 7199.

Fu, B., Lin, A., Kano, K.I., Maruyama, T., Guo, J., 2003. Quaternary folding of the eastern Tian Shan, northwest China. Tectonophysics, 369, 79-101.

Gallaud, A., 2008. Interaction Orogenèse - Climat - Erosion en Asie Centrale durant le Cénozoïque : L'impact de la surrection de la chaine du Tianshan sur le climat dans le bassin du Junggar. PhD Thesis, University Orléans, France, 376 pp. http://tel.archives-ouvertes.fr/tel-00361593/fr/

Galy, A., France-Lanord, C., 2001. Higher erosion rates in the Himalaya: geochemical constraints on riverine fluxes. Geology 29(1), 23-26.

Gao, J., Li, M., Xiao, X., Tang, Y., He, G., 1998. Paleozoic tectonic evolution of the Tianshan 
orogen, northwestern China. Tectonophysics 287, 213-231.

Giles, P.T., 2010. Investigating the use of alluvial fan volume to represent fan size in morphometric studies. Geomorphology 121, 317-328.

Granger, D.E., Kirchner, J.W., Finkel, R.C., 1996. Spatially averaged long-term erosion rates measured from in situ-produced cosmogenic nuclides in alluvial sediment. Journal of Geology 104, 249-257.

Graveleau, F., 2008. Interactions, Tectonique, Erosion, Sédimentation dans les avant-pays de chaînes : Modélisation analogique et étude des piémonts de l'est du Tian-Shan. PhD Thesis, Université Montpellier 2, France, 400 pp. http://tel.archives-ouvertes.fr/tel-00339145/en/

Hendrix, M.S., Dumitru, T.A., Graham, S.A., 1994. Late Oligocene-early Miocene unroofing in the Chinese Tian Shan: an early effect of the India-Asia collision. Geology 22, 487490.

Hinderer, M., 2012. From gullies to mountain belts: a review of sediment budgets at various scales. Sedimentary Geology 280, 21-59.

Jayko, A.S., 2005. Late Quaternary denudation, Death and Panamint Valleys, eastern California. Earth-Science Review 73, 271-289.

Jolivet, M., Dominguez, S., Charreau, J., Chen, Y., Li, Y., Wang, Q., 2010. Mesozoic and Cenozoic tectonic history of the Central Chinese Tian Shan: Reactivated tectonic structures and active deformation. Tectonics 29, TC6019, doi:10.1029/2010TC002712.

Jordan, P., Slaymaker, O., 1991. Holocene Sediment Production in Lillooet River Basin, British Colombia: A sediment Budget. Géographie physique et Quaternaire 45(1), 4557.

Kiefer, E., Dörr, M., Ibbeken, H., Götze, H.J., 1997. Gravity-based mass balance of an alluvial fan giant: the Arcas Fan, Pampa del Tamarugal, Northern Chile. Revista Geologica de Chile 24(2), 165-185.

Kuhlemann, J., 2002. Post-collisional sediment budget history of the Alps: tectonic versus climatic control. International Journal of Earth Sciences 91, 818-837.

Kuhlemann, J., 2007. Paleogeographic and paleotopographic evolution of the Swiss and Eastern Alps since the Oligocene. Global and Planetary Change 58, 224-236.

Lal, D., 1991. Cosmic ray labeling of erosion surfaces : in situ nuclide production rates and erosion models. Earth and Planetary Science Letters 104, 424-439.

Laurent-Charvet, S., Charvet, J., Shu, L.S., Ma, R.S., Lu, H.F., 2002. Palaeozoic late 
collisional strike-slip deformations in Tianshan and Altay, eastern Xinjiang, NW China. Terra Nova 14, 249-256.

Li, C., Dupont-Nivet, G., Guo, Z., 2011. Magnetostratigraphy of the northern Tian Shan foreland, Taxi He section, China. Basin Research 23, 101-117, doi: 10.1111/j.1365 2117.2010.00475.x.

Liu, Y., Métivier, F., Gaillardet, J., Ye, B., Meunier, P., Narteau, C., Lajeunesse, E., Han, T., Malverti, L., 2011. Erosion rates deduced from seasonal mass balance along the upper Urumqi River in Tianshan. Solid Earth 2, 283-301, doi:10.5194/se-2-283-2011.

Lu, H., Burbank, D.W., Li, Y., 2010a. Alluvial sequence in the north piedmont of the Chinese Tian Shan over the past $550 \mathrm{kyr}$ and its relationship to climate change. Palaeogeography, Palaeoclimatology, Palaeoecology 285, 343-353.

Lu, H., Burbank, D.W., Li, Y., Liu, Y., 2010b. Late Cenozoic structural and stratigraphic evolution of the northern Chinese Tian Shan foreland. Basin Research 22, 249-269, doi: 10.1111/j.1365-2117.2009.00412.x

Marr, J.G., Swenson, J.B., Paola, C., Voller, R., 2000. A two-diffusion model of fluvial stratigraphy in closed depositional basins. Basin Research 12, 381-398.

McWhorter, D.B, Sunada, D.K., 1977. Grounwater Hydrology and Hydraulics. Water Resources Publications, 290, U.S.A. pp.

Métivier, F., Gaudemer, Y., 1997. Mass transfer between eastern Tien Shan and adjacent basins (central Asia): constraints on régional tectonics and topography. Geophysical Journal International 128, 1-17.

Métivier, F., Gaudemer, Y., Tapponnier, P., Klein, M., 1999. Mass accumulation rates in Asia during the Cenozoic. Geophysical Journal International 137, 280-318.

Molnar, P., England, P., 1990. Late Cenozoic uplift of mountain ranges and global climate change: chicken or egg? Nature 346, 29-34.

Molnar, P., Brown, E.T., Burchfield, B.C., Deng, Q., Xianyue, F., Jun, L., Raisbeck, G.M., et al. 1994. Quaternary climate change and the formation of river terraces across growing anticlines on the north flank of the Tien Shan, China. Journal of Geology 102, 583-602.

Oguchi, T., 1997. Late Quaternary sediment budget in alluvial-fan-source-basin systems in Japan. Journal of Quaternary Science 12(5), 381-390.

Phillips, J., 2003. Alluvial storage and the long-term stability of sediment yields. Basin Research 15, 153-163.

Poisson, B., 2002. Impact du climat et de la tectonique sur l'évolution géomorphologique d'un piedmont, Exemple du piedmont Nord du Tian Shan depuis la fin du Pléistocène. Thèse 
de l’Université de Paris X. 260 pp.. http://tel.archives-ouvertes.fr/tel-00009710/

Poisson, B., Avouac, J-Ph., 2004. Holocene hydrological changes inferred from alluvial stream entrenchment in north Tian Shan (northwestern China). Journal of Geology 112, 231-249.

Puchol, N., Blard, P.H., Charreau, J., Pik, R., Lavé, J., Bourles, D., Dominguez, S., 2012. Paleo denudation rates from in-situ produced cosmogenic isotopes: method and new results from the Tian-Shan and the Himalayas. In: AGU Fall Meeting, San Francisco, CA.

Ramstein, G., Fluteau, F., Besse, J., Joussaume, S., 1997. Effect of orogeny, plate motion and land-sea distribution on Eurasian climate change over the past 30 million years. Nature 386, 788-795.

Raymo M.E., Ruddiman, W.F., 1992. Tectonic forcing of late Cenozoic climate. Nature 359, 117-122.

Ritz, J-F., Vassallo, R., Braucher, R., Brown, E.T., Carretier, S., Bourlès, D., 2006. Using in situ-produced ${ }^{10} \mathrm{Be}$ to quantify active tectonics in the Gurvan Bogd mountain range (Gobi-Altay, Mongolia). In: Siame, L.L., Bourlès, D.L., Brown, E.T. (Eds.), Application of Cosmogenic Nuclides to the Study of Earth Surface Processes: The Practice and the Potential. Geological Society of America Special Publication 415, 87-110, doi: 10.1130/2006.2415(06)

Shortridge, A., Messina, J., 2011. Spatial structure and landscape associations of SRTM error. Remote Sensing of Environment, 115, 1576-1587.

Smith, W.H.F., Wessel, P., 1990. Gridding with continuous curvature splines in tension. Geophysics 55, 293-305.

Sun, J., Zhu, R., Bowler, J., 2004. Timing of the Tianshan Mountains uplift constrained by magnetostratigraphic analysis of molasse deposits. Earth and Planetary Science Letters 219, 239-253.

Tapponnier, P., Molnar, P., 1977. Active faulting and tectonics of China. Journal of Geophysical Research 82, 2905-2930.

Vance, D., Bickle, M., Ivy-Ochs, S., Kubik, P.W., 2003. Erosion and exhumation in the Himalaya from cosmogenic isotope inventories of river sediments. Earth and Planetary Science Letters 206, 273-288.

Vassallo, R., Ritz, J-F., Braucher, R., Jolivet, M., Carretier, S., Larroque, C., Chauvet, A., Sue, C., Todbileg, M., Bourlès, D., Arzhannikova, A., Arzhannikov, S., 2007. Transpressional tectonics and stream terraces of the Gobi-Altay, Mongolia. Tectonics 
26, doi: 10.1029/2006TC002081.

von Blanckenburg, F., 2005. The control mechanism of erosion and weathering at basin scale from cosmogenic nuclides in river sediment. Earth and Planetary Science Letters 237, 462-479.

Wessel, P., Smith, W.H.F., 1991. Free software helps map and display data. EOS

Transaction of the American Geophysical Union 72, 445-446.

Wessel, P., Smith, W.H.F., 1995a. New version of the Generic Mapping Tools released.

EOS Transaction of the American Geophysical Union 76, 329.

Wessel, P., Smith, W.H.F., 1995b. New version of the Generic Mapping Tools released.

Transaction of the American Geophysical Union electronic supplement, http://www.agu.org/eos_elec/95154e.html.

Wessel, P., Smith, W.H.F., 1998. New, improved version of Generic Mapping Tools released, EOS Transaction of the American Geophysical Union 79, 579.

Whipple, K.X., Meade, B.J., 2006. Orogen response to changes in climatic and tectonic forcing. Earth and Planetary Science Letters 243, 218-228.

Whipple, K.X., Trayler, C.R., 1996. Tectonic control of fan size: The importance of spacially variable subsidence rates. Basin Research, 8, 351-366, doi:10.1046/j.1365-2117.

Willett, S.D., 1999. Orogeny and orography: the effect of erosion on the structure of mountain belts. Journal of Geophysical Research, 104(B12), 28, 957-28, 981.

Windley, B.F., Allen, M.B., Zhang, C., Zhao, Z.Y., Wang, G.R., 1990. Paleozoic accretion and Cenozoic redeformation of the Chinese Tien Shan range, central Asia. Geology 10, 128-131.

XBGMR, 1993. Regional Geology of Xinjiang Uygur Autonomy Region. Geological Memoirs, Ser. 1, 32, Map Scale 1/ 1,500,000, Geological Publishing House, Beijing, 841 pp.

Zhou, D., Graham, S.A., Chang, E.Z., Wang, B., Hacker, B., 2001. Paleozoic tectonic amalgamation of the Chinese Tian Shan: evidence from a transect along the Dushanzi-Kuqa Highway. In: Hendrix, M., Davis, S. (Eds.), Paleozoic and Mesozoic Tectonic Evolution of Central and Eastern Asia: From Continental 
Assembly to Intracontinental Deformation. Geological Society of America Memoir 194, Boulder, U.S.A., 71-99.

Zhou, S., Jiao, K., Zhao, J., Zhang, S., Cui, J., Xu, L., 2002. Geomorphology of the Urümqi River valley and the uplift of the Tianshan Mountains in Quaternary. Science in China (Series D) 45, 961-968.

\section{Figure caption.}

Fig. 1. Evidence for sediment storage in a valley of the Ih Bogd massif (Gobi Altay, Mongolia). The white Mongolian guers at the meeting point of the two valleys give the scale. The dash white line shows the boundary between the valley slopes and alluvial areas with sediment storage. To the west, the river started to incise the gravels stored in its valley and farther upstream, it incised a 25-m-deep canyon in the bedrock (Vassallo et al., 2007). Picture by A. Chauvet (with permission).

Fig. 2. General topographic and tectonic map of the central Chinese Tian Shan. The black box corresponds to Fig. 3. The hachured area corresponds to the distal part of the Kuitun river system.

Fig. 3. Morphosedimentary map of the Kuitun River drawn from SRTM3 data, Landsat ${ }^{\circledR} 7$, and Spot $^{\circledR} 5$ images, as well as from the images available through Google Earth ${ }^{\circledR}$. The areas in green represent surfaces uplifted by folding and thus reworked by erosion. Only the major drainage system is represented, but many other secondary and generally dry rivers exist. Pict. 5A to Pict. 5I refer to the locations of the individual pictures in Fig. 5. The brown dotted lines in the alluvial plain correspond to potentially old surfaces slightly emerging from the general sedimentation level. See text for discussion.

Fig. 4. Terraces and river bed profile of the Kuitun River through the Tian Shan Range and its piedmont. (A) Topographic measurements along the river profile, and (B) map of the 
piedmont terraces between the Dushanzi anticline to the north and the frontal basement thrust of the range to the south. River bed measurements were collected along an unfolded profile (e.g., Poisson, 2002). Point 0 was taken on the axis of the Dushanzi anticline (see Fig. 3 for location). The white area corresponds to the piedmont. The grey shaded area corresponds to the catchment within the basement rocks of the range. Following Poisson and Avouac (2004), the terraces in the piedmont are labelled $T_{1}$ to $T_{5}$ in decreasing age based on their respective altitude. The Pleistocene fan is labelled $f_{p}$. On the profile the surface of this Pleistocene fan $f_{p}$ is hardly distinguishable from the surface of the terrace $T_{1}$, as they are just a few vertical meters apart (see also Fig. 4B of Poisson and Avouac, 2004). The black dotted line running from the piedmont to the catchment corresponds to the regression line between the eastern terrace measurements inside the range (the vertical and horizontal error on the measured position of each terrace is included in the size of the symbols). $F_{1}$ and $F_{2}$ refer, respectively, to the frontal basement thrust and a potentially active second thrust fault within the range.

Fig. 5. Field pictures of the various morphosedimentary structures observed within the Kuitun catchment area from (A) the source of the river to $(\mathrm{J})$ its outlet in the Junggar Basin (i.e., to the major basement thrust $F_{1}$ that controls the front of the high range). See Fig. 3 for picture location and the text for a complete discussion.

Fig. 6. Measurement of the volume of sediments released from the Kuitun catchment during the Holocene. (A) DEM of the present-day topography of the catchment area in the range obtained from SRTM3 data. (B) Plane used to extend the surface of the Pleistocene fan $\mathrm{f}_{\mathrm{p}}$ within this catchment area (see text for explanation). The slope of this plane corresponds to the slope of the line passing through the two best-defined upper terraces on the eastern bank of the river (Fig. 4A). The white dots represent the location of these terraces. (C) Difference of elevation between (A) the present-day topography and (B) the paleosurface represented by the plane. (D) Zoom on this difference that corresponds, along with the local uplift of the fan surface generated by the recent growth of the Dushanzi anticline (see Fig. 6B of Poisson and Avouac, 2004), to the material eroded from the drainage system in the range during the Holocene.

Fig. 7. Measurement of the volume of sediments released from the Kuitun piedmont during the Holocene. (A) DEM of the present-day topography of the Kuitun canyon derived from SRTM3 data. (B) Example of calculated topography after filling up the canyon to the surface 
of the $T_{1}$ terrace level. (C) Difference of elevation between (A) the present-day topography and (B) the one estimated at the end of the Pleistocene. This difference corresponds to the material eroded from the Kuitun canyon.

Fig. 8. Measurements of the volume of sediments stored in the Kuitun Holocene fan. (A) DEM of the present-day topography of the fan obtained from SRTM3 data. (B) Topography of the base of the Holocene fan estimated using the front slope of the Pleistocene fan $f_{p}$ below the proximal part of the former and the mean slope of the surrounding alluvial plain below its distal part. (C) Difference of elevation between (A) the present-day topography and (B) the one assessed at the end of the Pleistocene This difference corresponds to the thickness of the material deposited in the Holocene fan. 


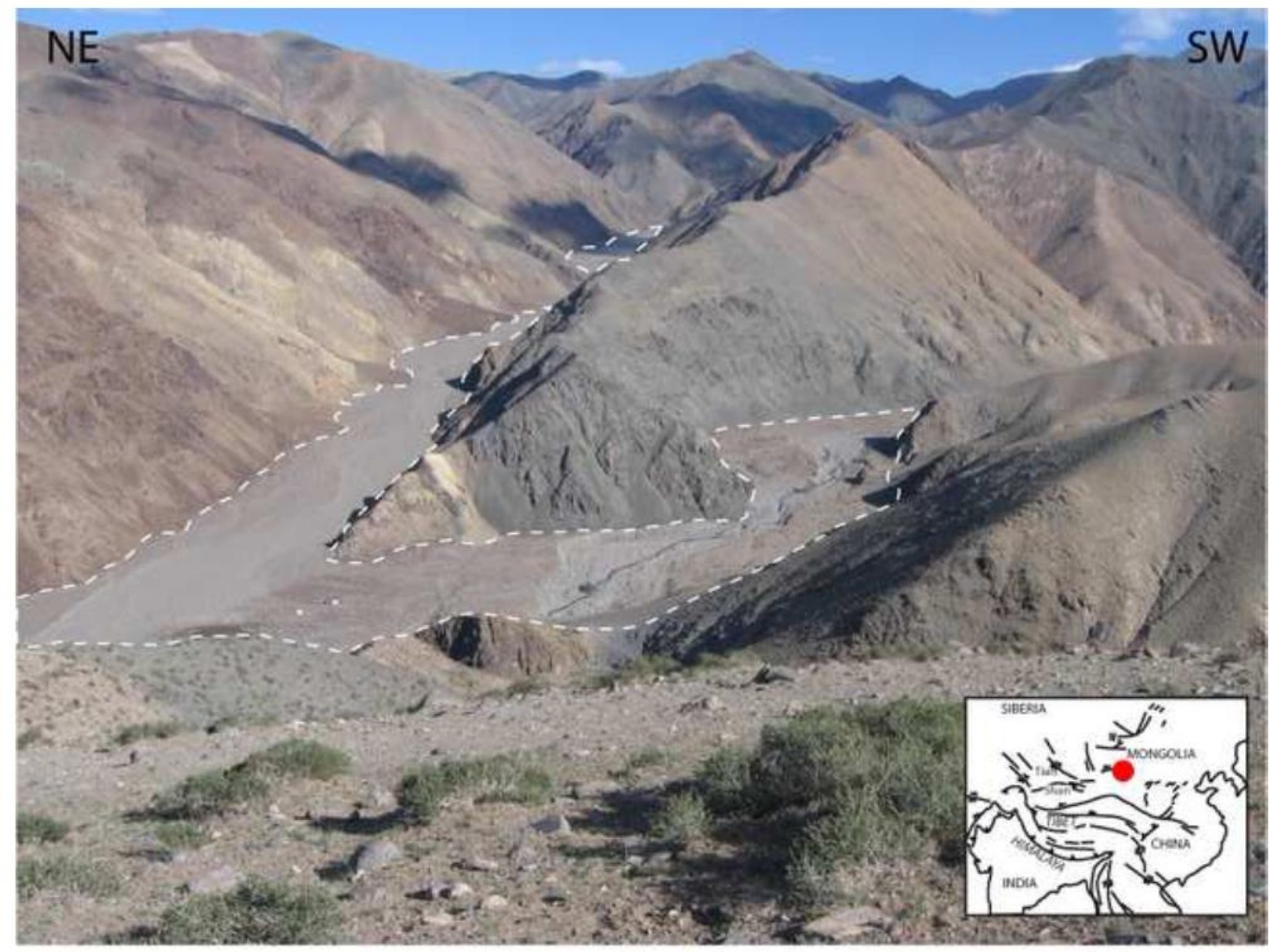

Figure 1

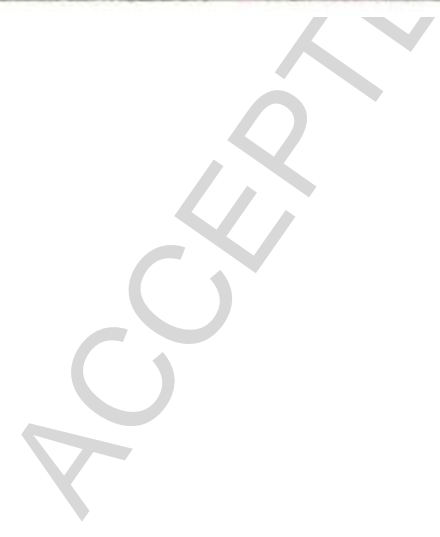




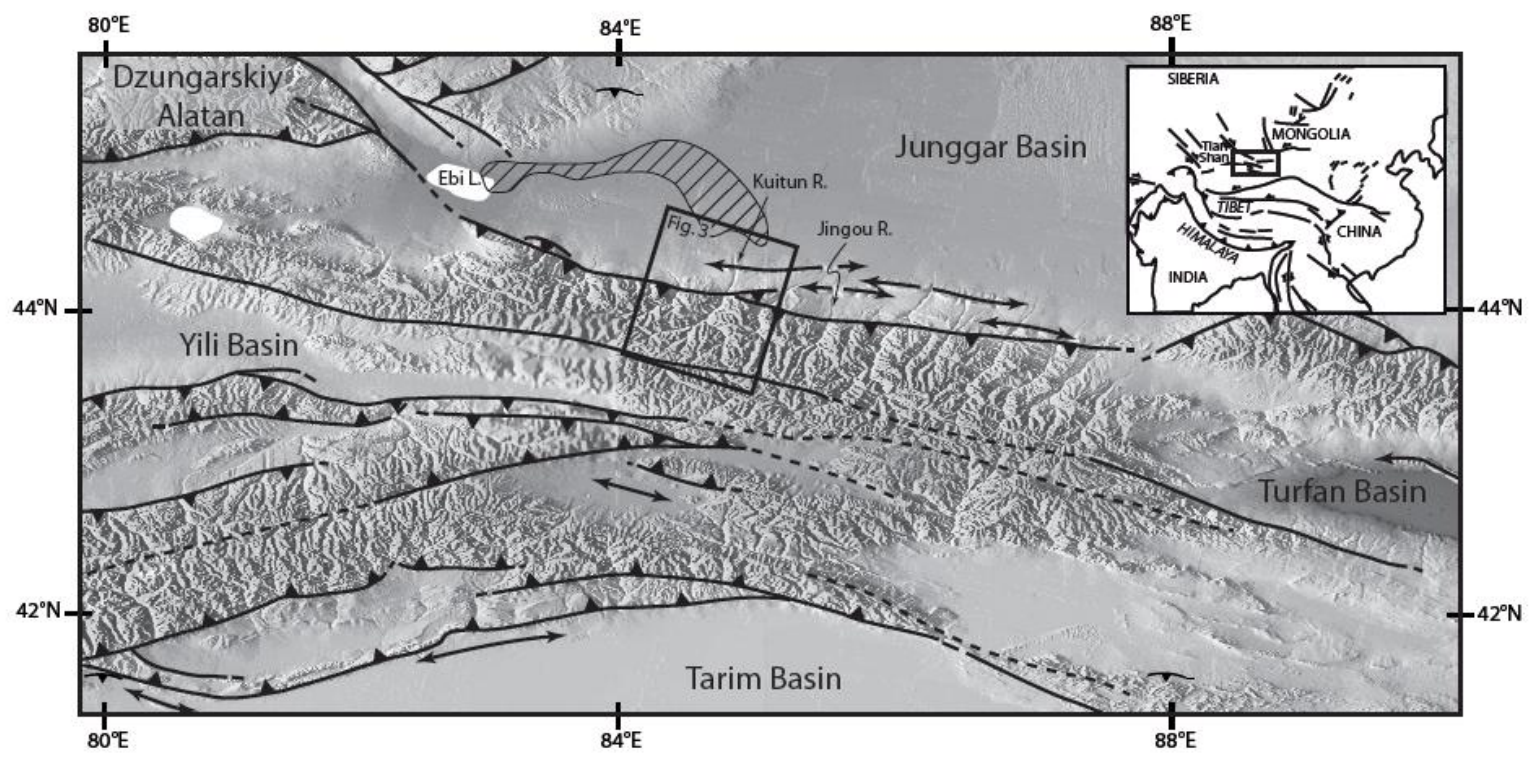

Figure 2 


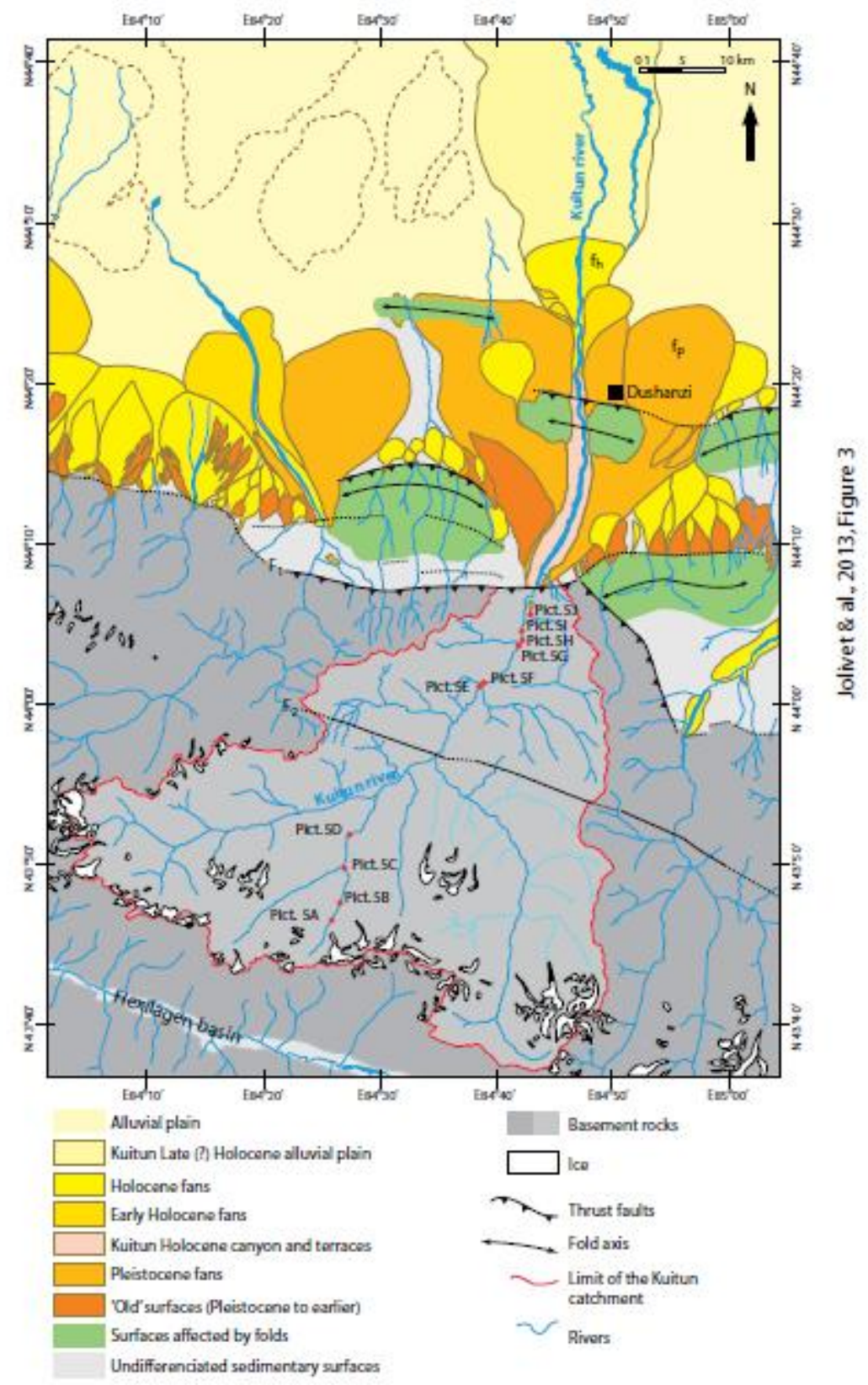

Figure 3 


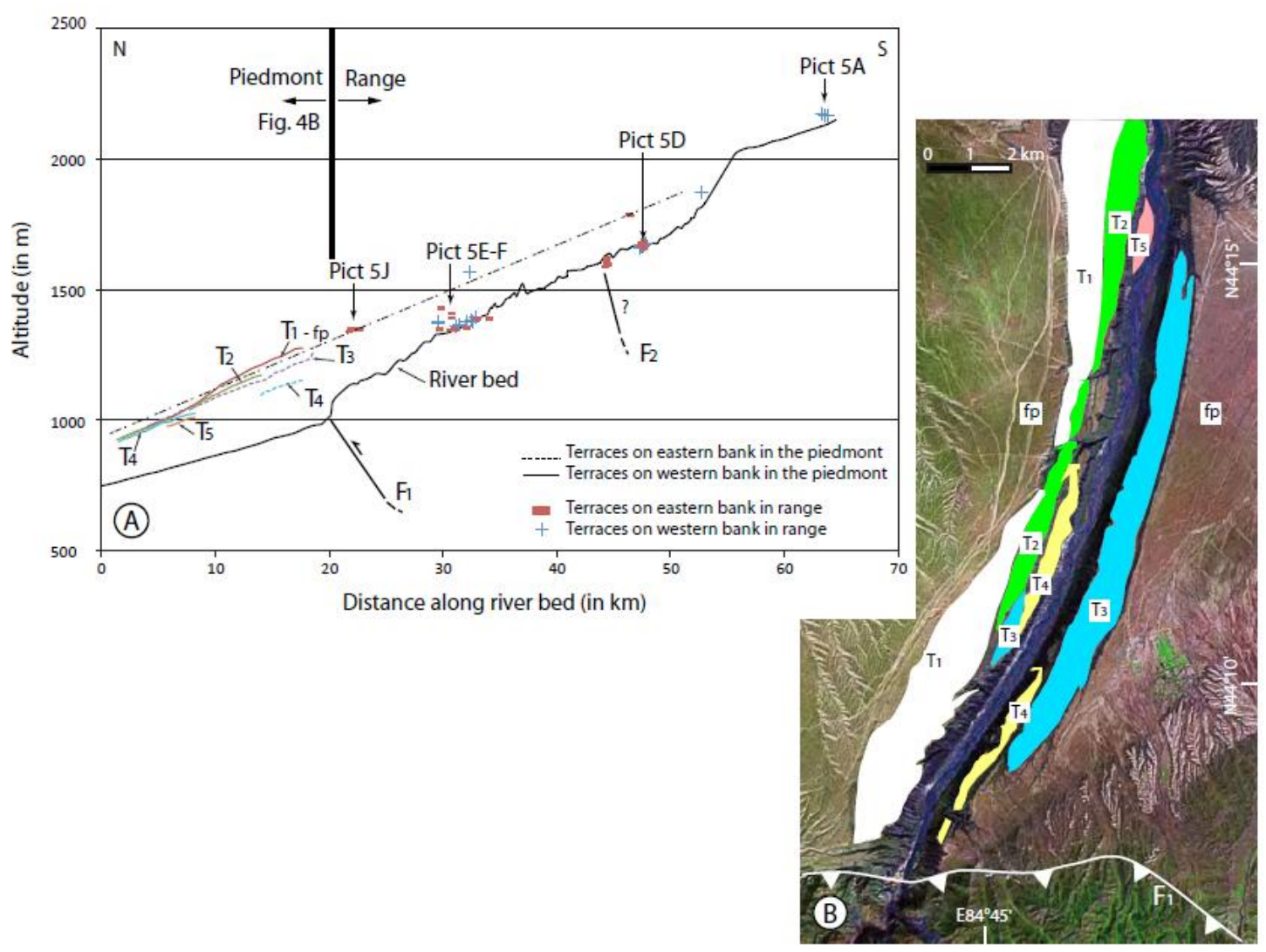

Figure 4 

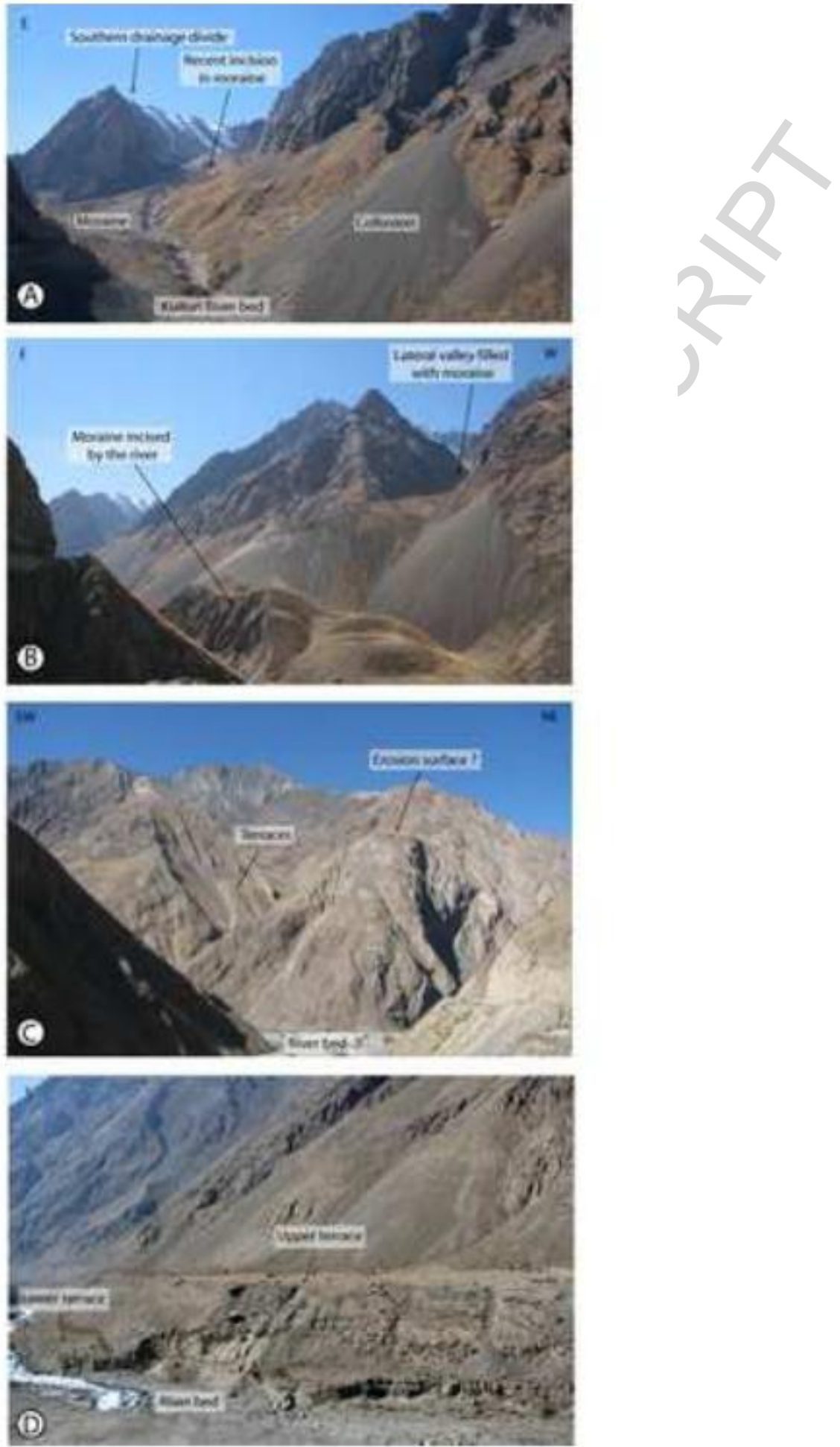

Figure 5a 


\section{ACCEPTED MANUSCRIPT}
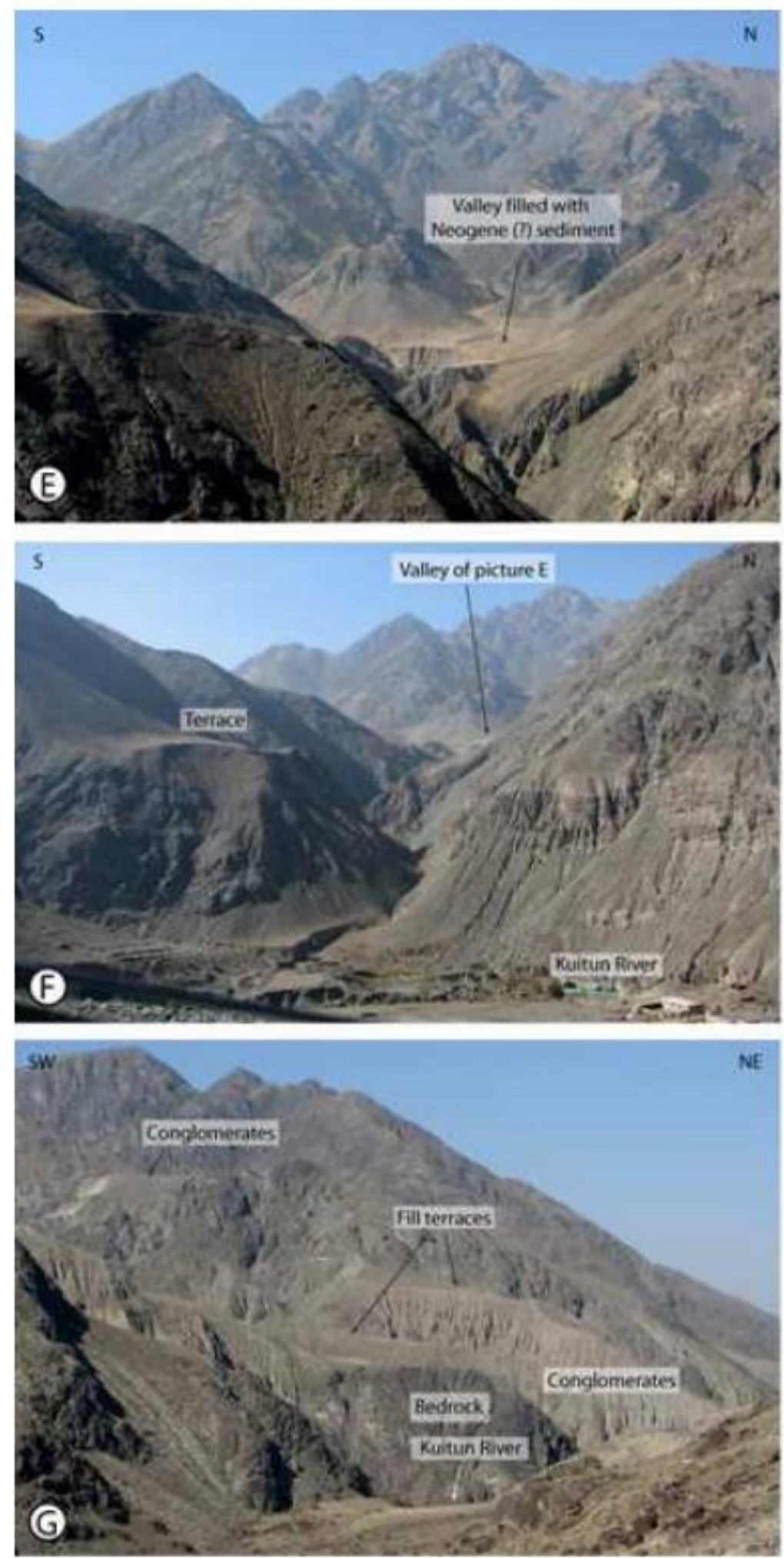

Figure 5b 


\section{ACCEPTED MANUSCRIPT}
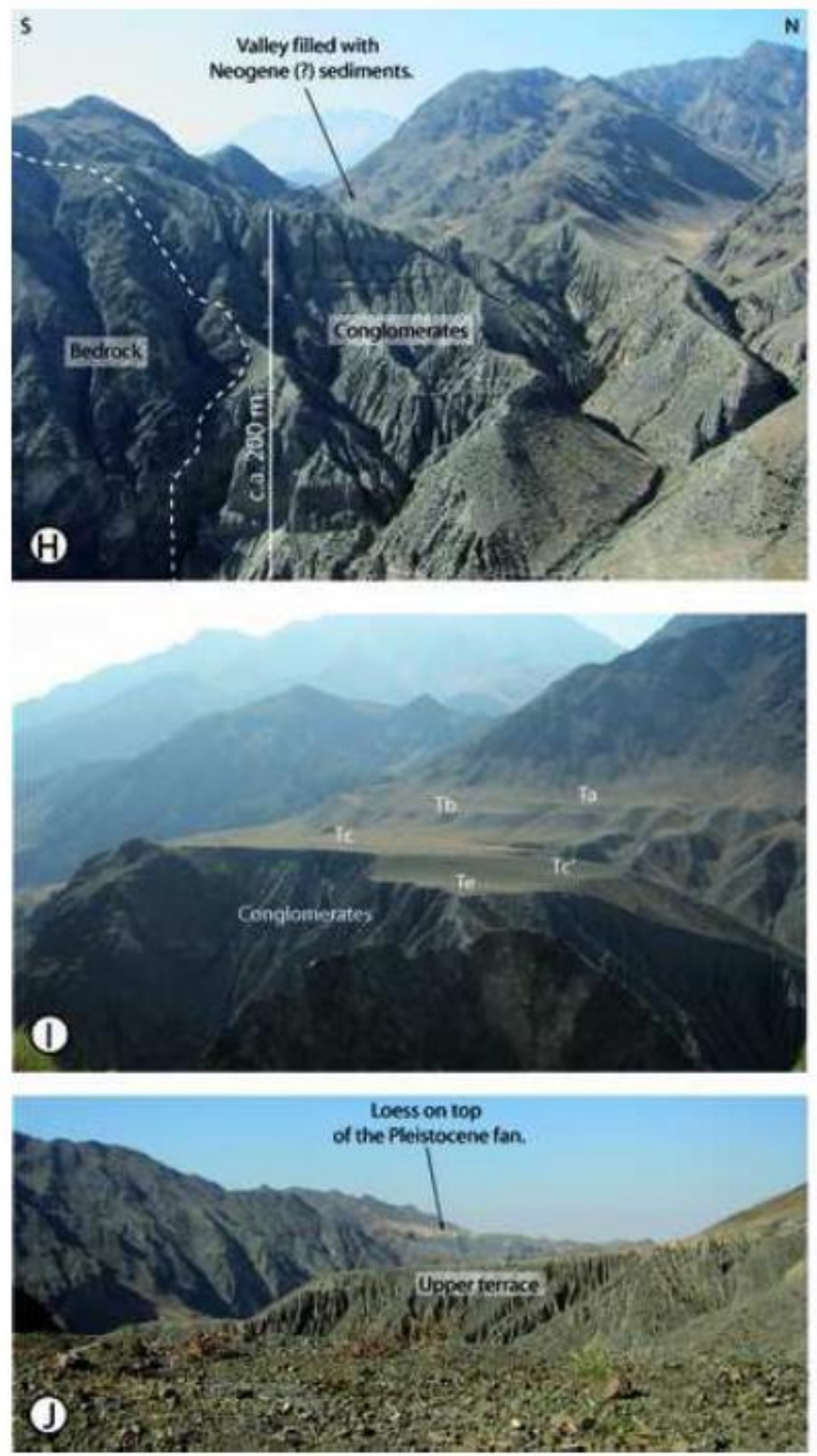

Figure 5c 


\section{ACCEPTED MANUSCRIPT}
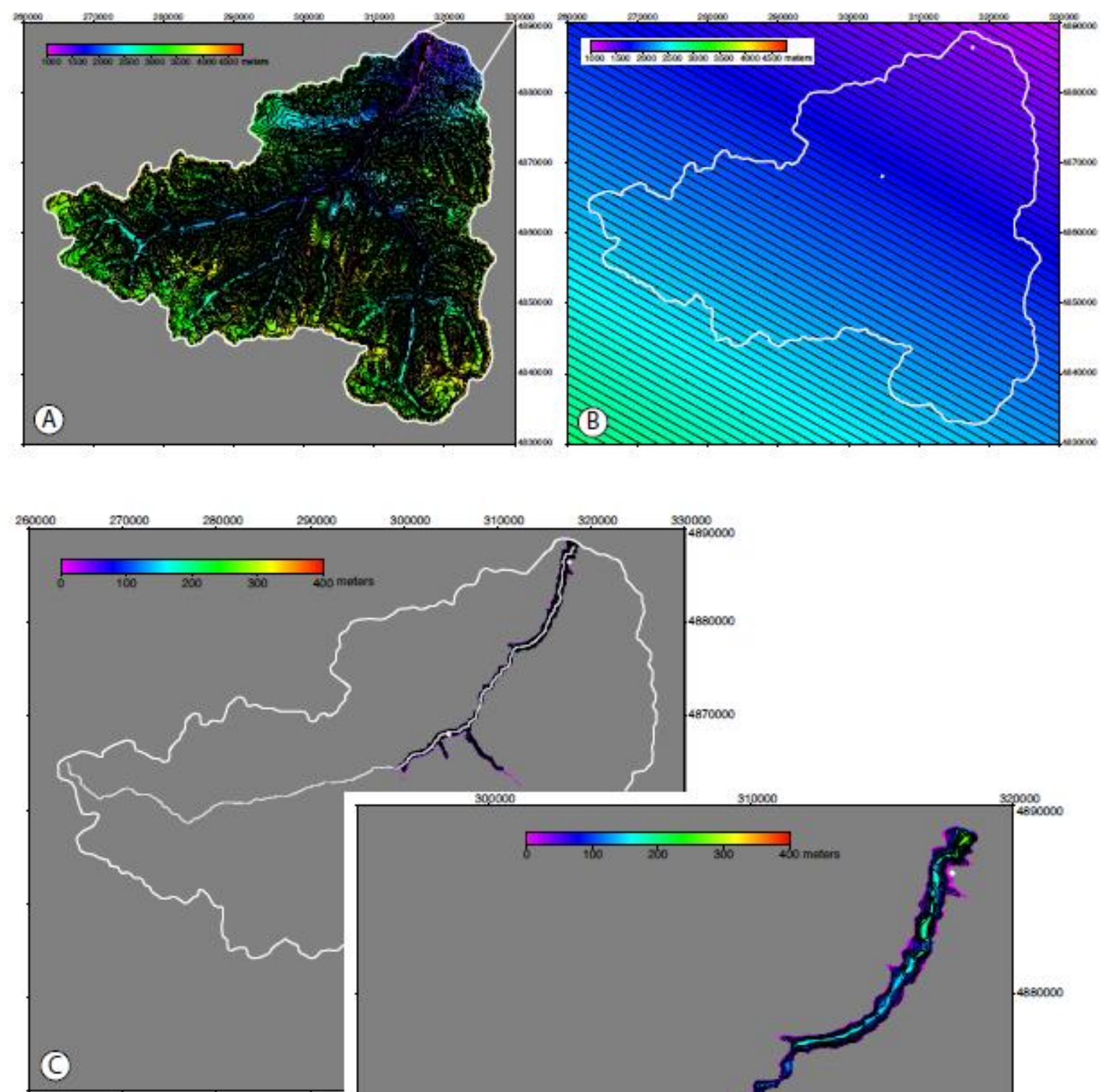

300000

$\$ 10000$

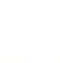



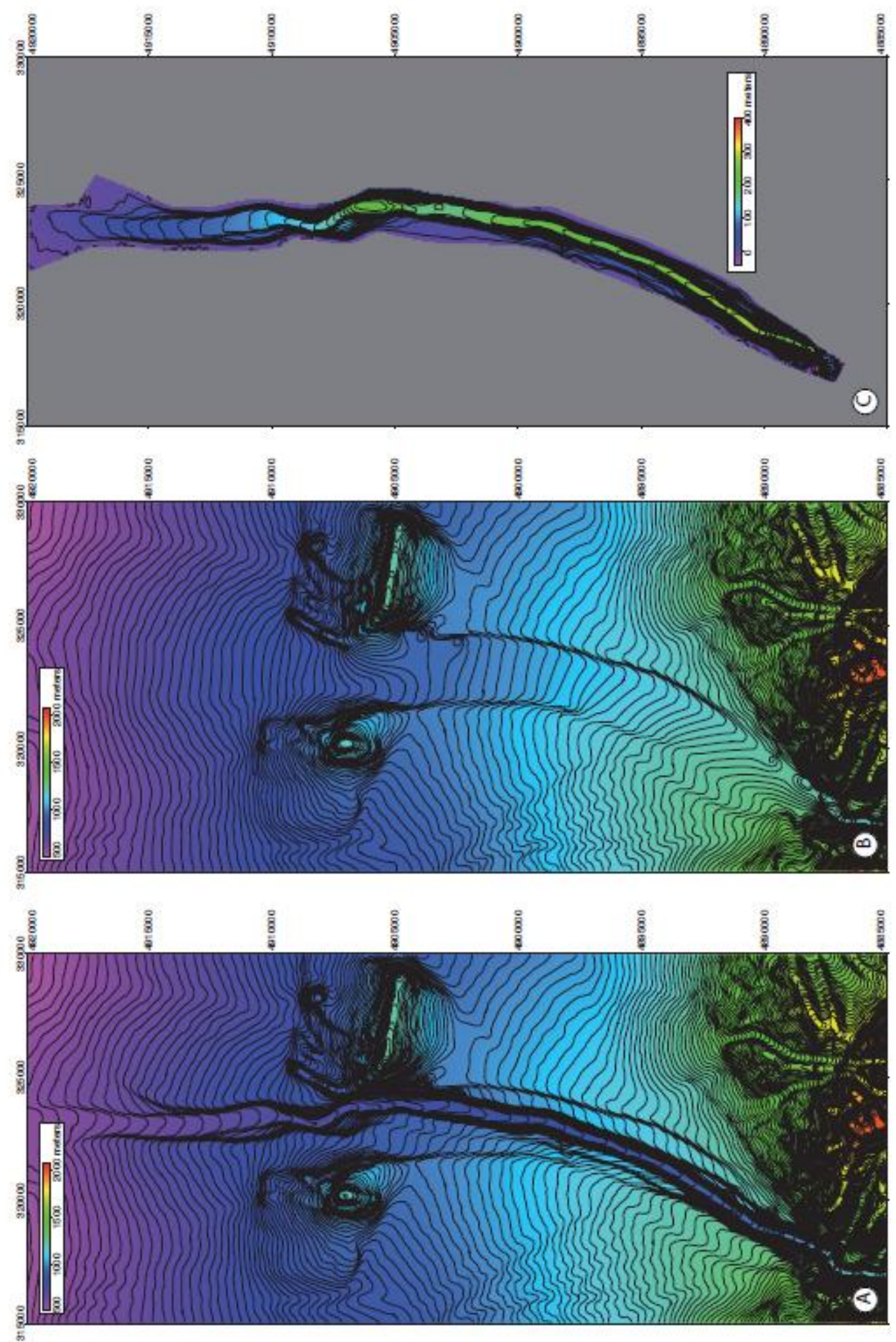

Figure 7 

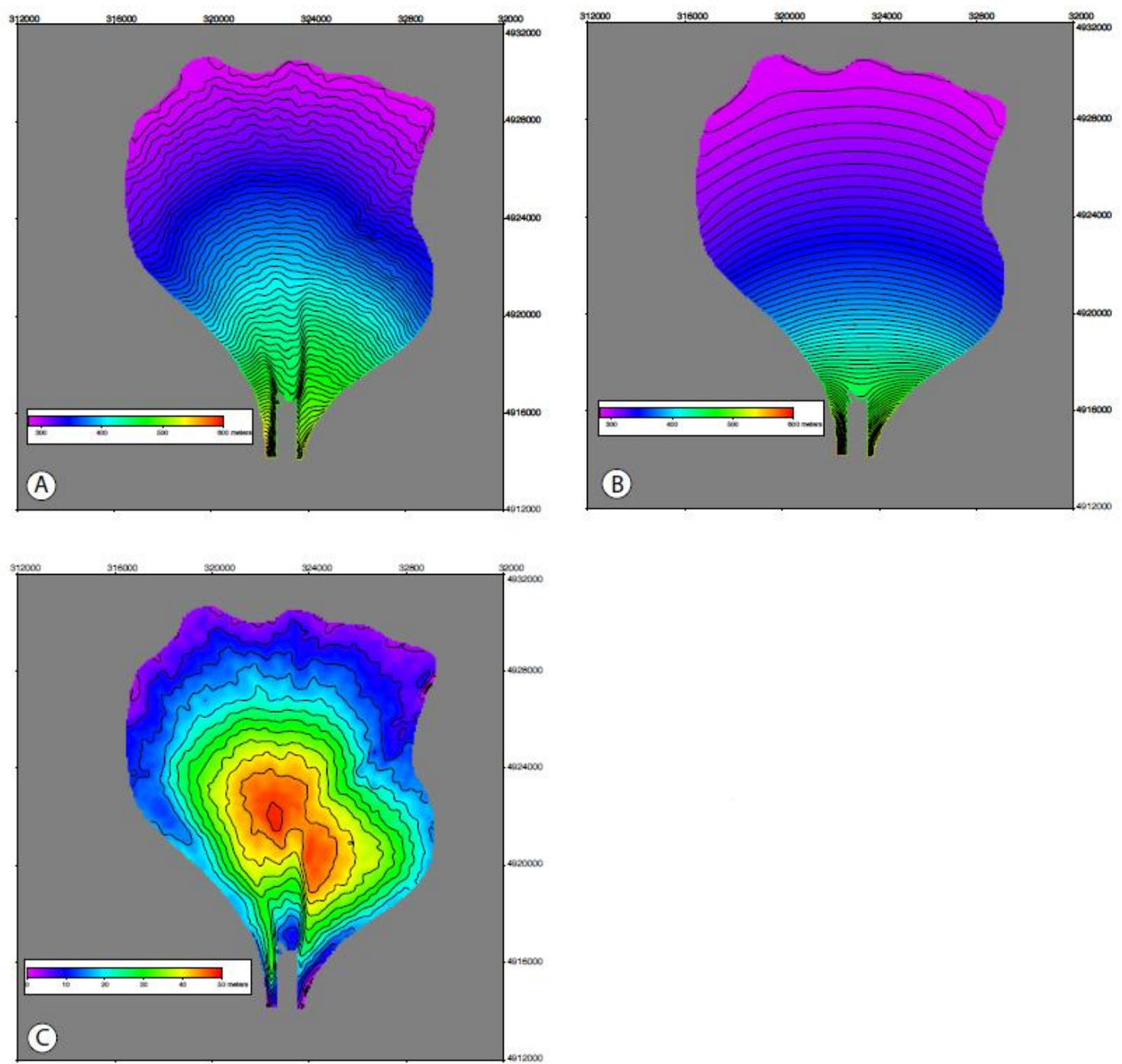

Figure 8 


\section{Highlights}

Significant sediment storage occurred in the catchment area during the Pleistocene. 30 to $70 \%$ of material bypassed the Holocene alluvial fan towards the alluvial plain. Major volumetric partitioning occurs between the alluvial fan and the alluvial plain. Volumetric partitioning might be driven by specific Holocene hydrological regime. Sediment storage and release complicates mean palaeo-erosion rates calculation. 